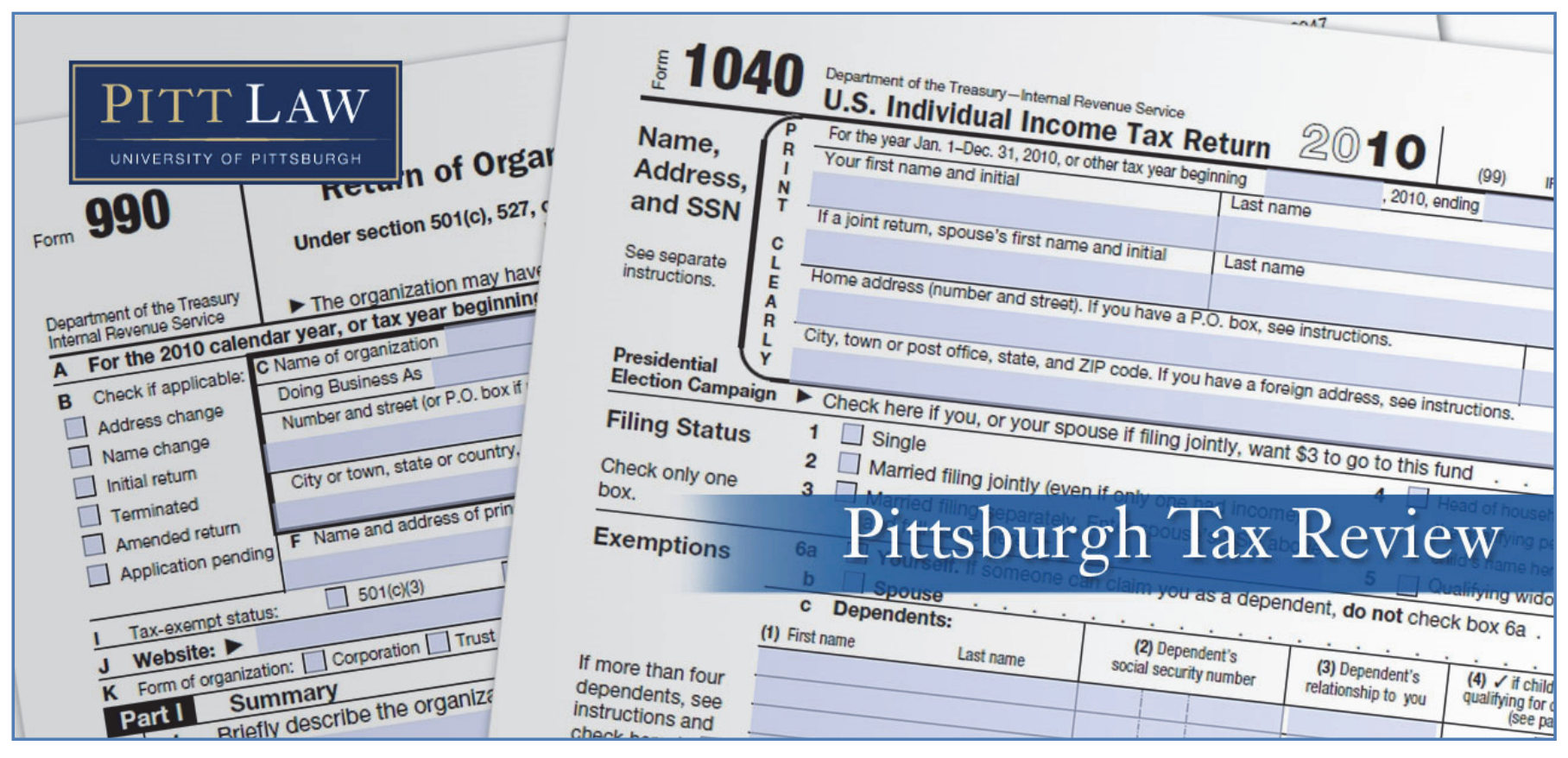

Volume 16 (2019) | ISSN 1932-1821 (print) 1932-1996 (online)

DOI 10.5195/taxreview.2019.101 | http://taxreview.law.pitt.edu

\title{
LOW INCOME HOUSING TAX CREDITS AND THE DANGERS OF PRIVATIZATION
}

\author{
Javon T. Henry
}

\section{$(\mathrm{cc})$ EY-NG-ND}

This work is licensed under a Creative Commons Attribution-Noncommercial-No Derivative Works 3.0 United States License.

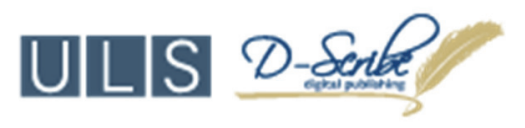

This journal is published by the University Library System of the University of Pittsburgh as part of its D-Scribe Digital Publishing Program, and is cosponsored by the University of Pittsburgh Press. 


\title{
LOW INCOME HOUSING TAX CREDITS AND THE DANGERS OF PRIVATIZATION
}

\author{
Javon T. Henry ${ }^{*}$
}

\section{INTRODUCTION}

Current federal affordable housing policy is ineffective because it is being used as a business platform to attract economic development instead of improving the quality of affordable housing. The low-income housing tax credit program (LIHTC or the Credit) is the largest national low-income affordable housing program. ${ }^{1}$ The federal government enacted LIHTC, which is found in $\S 42$ of the Internal Revenue Code (Code), to stimulate the involvement of the private sector in affordable housing by enticing real estate developers with tax credits in exchange for the construction of low-income housing units. ${ }^{2}$

However, a problem has arisen with regard to where developers locate these affordable housing units. ${ }^{3}$ Federal guidelines require that states allocate tax credits in a manner that facilitates cycles of poverty and maintains economic and racial segregation. ${ }^{4}$ The LIHTC program requires states to give

* JD Candidate, 2019, University of Pittsburgh School of Law. I would like to give a special thanks to Professor Gerald Dickinson for his advice, insight, generosity, and mentorship. I would also like to thank Professor Anne Bauer, Professor Anthony Infanti, and the Pittsburgh Tax Review members. I would also like to give a special shout out to some of my mentors: the Hon. ShawnDya Simpson, Professor Jodi Roure, Hon. François Rivera, Hon. Edgardo Ramos, Dean Kevin Deasy, Roberto G. Lebron, and Dr. Jermaine Wright.

${ }^{1}$ I.R.C. $\S 42(\mathrm{~g})(1)(\mathrm{A})$; NAT'L Multifamily Hous. Council, Low-InCOME Housing TAX CREDIT (LIHTC) 1 (2018), https://www.nmhc.org/uploadedFiles/Advocacy/Issue_Fact_Sheet/ LIHTC\%202015-1(3).pdf. "At its peak, the LIHTC program generated approximately 140,000 jobs and $\$ 1.5$ billion in state and local tax revenues annually; it has financed nearly 2.8 million apartments and served 13.3 million residents since its inception in 1986." Id.

${ }^{2}$ See H.R. REP. No. 99-841, at 4173 (1986) (Conf. Rep.).

${ }^{3}$ See discussion infra Part III.A.

${ }^{4}$ See discussion infra Part II.B.

Pitt Tax Review | ISSN 1932-1821 (print) 1932-1996 (online) DOI 10.5195/taxreview.2019.101 | http://taxreview.law.pitt.edu 
preference to qualified census tracts (QCT) ${ }^{5}$ which are areas with high levels of concentrated poverty. ${ }^{6}$ Consequently, LIHTC units are frequently built in high-poverty neighborhoods. ${ }^{7}$ Confining low-income housing developments to areas already plagued by poverty limits a tenant's ability to achieve economic and racial integration. ${ }^{8}$

Section 3608(d) of the Fair Housing Act $^{9}$ (FHA) mandates that all federal agencies with regulatory authority over financial institutions administer housing programs "in a manner [that] affirmatively . . . further[s] [fair housing]." 10 Under $\S 3613$ of the FHA, an injured party can make a claim that a housing program was administered in a manner that resulted in a disparate impact. ${ }^{11}$ However, after Texas Department of Housing and Community Affairs v. Inclusive Communities Project (ICP), ${ }^{12}$ the Supreme Court made it difficult for litigants to survive the pleading stages for disparate impact claims to hold private developers accountable to fair housing requirements. ${ }^{13}$ The Supreme Court allows private developers to use business decisions as a legitimate justification for placing affordable housing units in

${ }^{5}$ I.R.C. $\S 42(\mathrm{~m})(1)(\mathrm{A})(\mathrm{i}),(\mathrm{B})(\mathrm{ii})(\mathrm{III})$.

${ }^{6} I d$. $\S 42(\mathrm{~d})(5)(\mathrm{B})(\mathrm{ii})$ (defining “qualified census tracts”).

${ }^{7}$ See discussion infra Part IV.B.

${ }^{8}$ See generally Katherine M. O'Regan \& John M. Quigley, Accessibility and Economic Opportunity, in ESSAYS IN TRANSPORTATION ECONOMICS AND POLICY: A HANDBOOK IN HONOR OF JOHN R. MEYER 437 (José A. Gómez-Ibáñez et al. eds., 1999) (discussing the impact location can have on employment). Scholars agree that the quality of a neighborhood contributes to a person's quality of life and economic opportunity. See id. at 454-55. A study conducted by O'Regan found that residential location can explain ten to forty percent of the observed outcomes of racial differences in youth employment. Id. at 458. Another study demonstrates that children growing up in low-income neighborhoods perform poorly compared to children growing up in higher-income neighborhoods. Jeanne Brooks-Gunn et al., Do Neighborhoods Influence Child and Adolescent Development?, 99 AM. J. Soc. 353, 384 (1993).

${ }^{9}$ Fair Housing Act, Pub. L. No. 90-284, § 801, 82 Stat. 73, 81 (1968) (codified at 42 U.S.C. § 3601).

${ }^{10} 42$ U.S.C. $\$ 3608$ (d) (2012); see also 114 CONG. REC. 3422 (1968) (remarks of Sen. Mondale) (discussing how one of the purposes of the act is to replace ghettos with "truly integrated and balanced living patterns").

${ }^{11} 42$ U.S.C. $\$ 3623(a)(1)(A)$; accord Barrett v. H \& R Block, Inc., 652 F. Supp. 2d 104, 116 (2009) (using 42 U.S.C. $\S 3613$ as the mechanism for asserting a disparate impact claim against a creditor).

${ }^{12}$ See Tex. Dep't of Hous. \& Cmty. Affairs v. Inclusive Cmtys. Project, Inc., 135 S. Ct. 2507, 2524 (2015). This case will be discussed infra Part IV.B.

${ }^{13}$ See generally Inclusive Cmtys., 135 S. Ct. at 2507.

Pitt Tax Review | ISSN 1932-1821 (print) 1932-1996 (online)

DOI 10.5195/taxreview.2019.101 | http://taxreview.law.pitt.edu 
areas that are contrary to fair housing goals. ${ }^{14}$ In other words, private developers are provided a loophole when it comes to compliance with the Fair Housing Act.

The federal government did not always rely on the private sector to create affordable housing. ${ }^{15}$ The federal government originally provided affordable housing by way of public housing, which was subsidized through federal funds and managed by local housing authorities. ${ }^{16}$ Unfortunately, public housing has a long history of racial discrimination, poor management, and minimal financial support. ${ }^{17}$ The failure of public housing has made it easy for Congress to step away from state-controlled public housing and to look to the private market to provide affordable housing. ${ }^{18}$ The Supreme Court also supported this transition to the private market, as illustrated by Gautreaux v. Chicago Housing Authority. ${ }^{19}$ In that case, the Court concluded that housing authorities can further fair housing efforts by relying on the private market with Section 8 of the Housing Act of 1937, which authorizes a voucher program to subsidize a private provision of public housing. ${ }^{20}$

LIHTC builds on Gautreaux and represents another step towards the exclusive reliance on the private sector to provide affordable housing. ${ }^{21}$ With this transition, the federal government has passed the responsibility onto private parties - developers, real estate agents, contractors, and banks - to decide where affordable housing properties will be built. ${ }^{22}$ This is important

${ }^{14}$ See id. at $2522-23$.

${ }^{15}$ See discussion infra Part I.

${ }^{16}$ See discussion infra Part I.

${ }^{17}$ See discussion infra Part I.

${ }^{18}$ See discussion infra Part IV.B.

${ }^{19}$ Hills v. Gautreaux, 425 U.S. 284, 306 (1976).

${ }^{20}$ See id. at 303-06 (discussing the benefits of using the Section 8 program as a remedy); see also 42 U.S.C. $§ 1437 f(0)(2012)$.

${ }^{21}$ See discussion infra Part IV.

${ }^{22}$ See discussion infra Part II; see also Kimberly N. Brown, "We the People," Constitutional Accountability, and Outsourcing Government, 88 IND. L.J. 1347, 1361-63 (2013) (discussing how the "government should structure its contractual relationships with the private sector"). Private entities escape legal accountability measures imposed on public entities, such as electoral approval, due process, and

Pitt Tax Review | ISSN 1932-1821 (print) 1932-1996 (online) DOI 10.5195/taxreview.2019.101 | http://taxreview.law.pitt.edu 


\section{0 | Pittsburgh Tax Review | Vol. 162019}

because the area where one lives significantly influences one's overall quality of life, job opportunities, and education. ${ }^{23}$ Meanwhile, the Fair Housing Act mandates that the government take a nondiscriminatory approach. ${ }^{24}$ Private entities are not held to the same standard as the government because the Court's decision in ICP made it feasible for private developers to circumvent fair housing requirements. ${ }^{25}$

This Note seeks to explain how the evolution of federal housing policy has shifted from an exclusively public system of subsidized affordable housing to an increasingly privatized industry with the LIHTC. As federal housing policy has shifted from purely public to mostly private, so has the discriminatory effect of federal and state housing policy of federal and state agencies. ${ }^{26}$ The public-private transition has not only made racial discrimination more likely, but made it more difficult to identify as well. ${ }^{27}$ Gautreaux and ICP capture the essence of that struggle. Ultimately, this Note proposes that we swing the pendulum back towards a robust "public" approach to affordable housing in order to reduce discrimination and segregation as well as eliminate the barriers to relief imposed by the Court in ICP.

This Note proceeds as follows: Part I provides an overview of public housing and its history. This section further examines the key reasons to why public housing has failed. Part II describes the structure of Section 8 and LIHTC. Part III argues that the Gautreaux case helped set the stage for transitioning to relying on the private sector to provide affordable housing. Part IV then argues that the full transition to relying on the private market with LIHTC has only permitted racial segregation and the Court in ICP has

sunshine laws. See generally GOVERNMENT BY CONTRACT: OUTSOURCING AND AMERICAN DEMOCRACY (Jody Freeman \& Martha Mino eds., 2009).

${ }^{23}$ William Julius Wilson, The Truly Disadvantaged: The InNer City, the Underclass, AND PUBLIC POLICY 56 (2d ed. 2012). By placing minorities in areas that have few advantages, private developers are allowing minorities to remain in poverty. $I d$. $\S 3601)$.

${ }^{24}$ Fair Housing Act, Pub. L. No. 90-284, § 801, 82 Stat. 73, 81 (1968) (codified at 42 U.S.C.

${ }^{25}$ See Tex. Dep't of Hous. \& Cmty. Affairs v. Inclusive Cmtys. Project, Inc., 135 S. Ct. 2507, 2524 (2015). This Supreme Court case is discussed infra Part IV.B.

${ }^{26}$ See discussion infra Part IV.A.

${ }^{27}$ See discussion infra Part IV.B.

Pitt Tax Review | ISSN 1932-1821 (print) 1932-1996 (online) DOI 10.5195/taxreview.2019.101 | http://taxreview.law.pitt.edu 
only made it difficult for plaintiffs to survive the pleading stages of litigation. Lastly, Part IV proposes the solution of switching back to state-controlled affordable housing where the state housing authorities use the tax credits.

\section{OVERVIEW OF PUBLIC HOUSING}

Before LIHTC and Section 8, public housing was the main form of subsidized low-income housing in the United States. ${ }^{28}$ As the oldest form of low-income housing, public housing evokes many negative attributes because of its various failures over the years. ${ }^{29}$ To begin, in order to rectify the current reliance on the private sector, we need to understand public housing and where housing authorities have gone wrong with operating public housing buildings.

During the Great Depression of the 1930s, many Americans were in poverty. ${ }^{30}$ President Franklin Delano Roosevelt created the New Deal to respond to the country's economic downturn. ${ }^{31}$ As part of the last section of the New Deal, the Housing Act of $1937^{32}$ created the first set of public housing projects. ${ }^{33}$ The Housing Act of 1937 authorized State Housing Authorities $^{34}$ (Authorities or PHAs) to issue bonds to finance the

\footnotetext{
${ }^{28}$ See infra Part II.A-B (discussing when the new affordable housing policies were enacted).

${ }^{29}$ Cara Hendrickson, Racial Desegregation and Income Deconcentration in Public Housing, 9 GEO. J. POVERTY LAW \& POL'Y 35, 36 (2002).

${ }^{30}$ Brian G. Gilmore, What Are the Poor Doing Tonight?: Incorporating Social Justice into the Law School Ethos, 15 SEATTLE J. SOC. JUST. 357, 367 (2016) (discussing the meaning of poverty and poverty during the Great Depression).

${ }^{31}$ Gail Radford, The Federal Government and Housing During the Great Depression, in FrOM TENEMENTS TO THE TAYLOR HOMES 104 (John F. Bauman et al. eds., 2000).

${ }^{32}$ United States Housing Act of 1937, Pub. L. No. 75-412, 50 Stat. 888.

${ }^{33}$ Radford, supra note 31, at 110. During the Great Depression, suburban construction of private housing stopped. $I d$. at 107 . Working-class and middle-class families were losing their homes because they became unemployed. Id. To address this economic downturn, the federal government enacted the New Deal Policy, which created the Housing Act of 1937. Id. at 110. "The program replaced a much smaller New Deal initiative that financed the development of low-income housing as part of a broader effort to support public works." Alex F. SChwartZ, Housing POLICY IN THE United States 163 (2014).

${ }^{34}$ The state created organization is referred to as a "public housing agency" by the Housing Act of 1937. United States Housing Act of $1937 \S 2(11), 50$ Stat. at 889 . This paper shall use the term "housing
}

Pitt Tax Review | ISSN 1932-1821 (print) 1932-1996 (online) DOI 10.5195/taxreview.2019.101 | http://taxreview.law.pitt.edu 


\section{2 |Pittsburgh Tax Review | Vol. 162019}

development of public housing. ${ }^{35}$ The federal government paid the interest on these bonds. ${ }^{36}$ PHAs used tenants' rent to pay for operational costs. ${ }^{37}$ Since its inception in the 1930s, however, PHAs were set up for failure, primarily attributable to the structure of the program itself, methods of tenant selection, cost restrictions, compounding financial limitations, and the racial discrimination that is inherent in federal housing policy. ${ }^{38}$

\section{A. Public Housing}

Federal public housing policy paired local housing authorities with the federal government. Public housing properties are owned and managed by "quasi-governmental local public housing authorities." 39 PHAs entered into contracts with the federal government called Annual Contribution Contracts. ${ }^{40}$ Under the terms of these agreements, PHAs agreed to administer public housing pursuant to federal rules and regulations in exchange for federal funding. ${ }^{41}$ States created PHAs largely to capitalize on this new source of federal funding. ${ }^{42}$

Public housing provides assistance to low-income families. ${ }^{43}$ To be eligible for public housing programs, families must meet certain income

authorities" to refer to all state and local government entities authorized to engage in the development or operation of public housing.

${ }^{35}$ SCHWARTZ, supra note 33 , at 163 .

${ }^{36} I d$. at $163-64$.

${ }^{37} \mathrm{Id}$. at 164 .

${ }^{38}$ Maggie McCarty, Cong. Research Serv., R41654, Introduction to Public Housing 9 (2014), https://fas.org/sgp/crs/misc/R41654.pdf.

${ }^{39} \mathrm{Id}$.

${ }^{40} I d$.

${ }^{41} I d$. PHAs are required to create an annual plan that must include information regarding housing needs in the community, application information, financial resources, and policies. Id. at 11.

${ }^{42} I d$. at 9 . States decided how members of the authority are selected, whether they are appointed by the governor or mayor or are elected. Id. The state also decides what type of housing policy they work on (e.g., federal public housing or state and local affordable housing) or whether they can act as affordable housing developers. Id.

${ }^{43} I d$. at 17.

Pitt Tax Review | ISSN 1932-1821 (print) 1932-1996 (online) DOI 10.5195/taxreview.2019.101 | http://taxreview.law.pitt.edu 
standards. ${ }^{44}$ To qualify, families generally must be at or below eighty percent of the area median income (AMI) when they apply for housing. ${ }^{45}$ Eligible tenants are required to pay rent that is no more than thirty percent of their adjusted gross income. ${ }^{46}$

Public housing comes in a variety of different sizes and types. ${ }^{47}$ The most common form is smaller-scale housing such as townhouses, row houses, walk-up, garden-style detached, semidetached homes, and scattered site housing. ${ }^{48}$ Meanwhile, high-rise and mixed developments account for less than one-quarter of all public housing. ${ }^{49}$

\section{B. Tenant Selection}

PHAs' selection criteria are important because they receive their budget from the rent that they charge tenants, and the budget is used to cover operational expenses. ${ }^{50}$ Thus, if PHAs select tenants who cannot meet their operational costs, then PHAs will need to locate other funding sources or reduce operating costs. ${ }^{51}$ Again, the federal government agreed it would pay the building costs, and the state, through their PHAs, would use the rents to cover operational expenses. ${ }^{52}$ PHAs are limited to charging tenants a maximum of thirty percent of their income. ${ }^{53}$ If PHAs select middle-income tenants, as opposed to lower-income tenants, then they will have a larger budget to cover expenses. ${ }^{54}$ Beginning in the $1930 \mathrm{~s}$, the tenants selected to

\footnotetext{
${ }^{44} I d$.

${ }^{45} I d$.

${ }^{46} I d$. at 19.

${ }^{47} I d$. at 26 .

${ }^{48} \mathrm{Id}$.

${ }^{49} I d$.

${ }^{50} I d$. at 9.

${ }^{51}$ Public Housing, NAT'L Hous. LAW PROJeCt, https://www.nhlp.org/resource-center/publichousing/ (last visited Apr. 16, 2019).

${ }^{52}$ MCCARTY, supra note 38 , at 9.

${ }^{53} I d$. at 19 (discussing thirty percent limit on rent).

${ }^{54} \mathrm{Id}$.
}

Pitt Tax Review | ISSN 1932-1821 (print) 1932-1996 (online) DOI 10.5195/taxreview.2019.101 | http://taxreview.law.pitt.edu 


\section{4 | Pittsburgh Tax Review | Vol. 162019}

live in public housing only got poorer. ${ }^{55}$ Because of this change, PHAs are having a difficult time meeting their operational costs as originally stipulated with the federal government. ${ }^{56}$

Originally, public housing was created to provide adequate housing for middle-class workers who were made homeless by the Great Depression. ${ }^{57}$ Real estate agents and bankers expressed their concerns about public housing because they thought "renting from the government might prove so attractive that the urge to buy one's own home will be diminished."58 They feared that public housing would interfere with their private enterprises because it would ultimately remove a large segment of the population from the private housing market. ${ }^{59}$ To garner support for public housing, advocates agreed that tenants should be selected in a manner that does not compete with the private housing market. ${ }^{60}$ Accordingly, public housing began by only housing families in the lower end of the financial spectrum. ${ }^{61}$ Because PHAs were limited to only targeting families with lower incomes, they received less money to cover financial costs, which later resulted in PHAs' general difficulty with financing operational costs. ${ }^{62}$

Many PHAs entered financial deficits or relied entirely on federal subsidies in order to continue operations. ${ }^{63}$ Over the course of time, the demographics of public housing tenants became increasingly impoverished and disproportionately comprised of racial and ethnic minorities. ${ }^{64}$ Many white families were moving out of public housing because they could get a home in the suburbs through the Fair Housing Act's and the GI bill's home

\footnotetext{
${ }^{55}$ SCHWARTZ, supra note 33, at 167.

${ }^{56} \mathrm{Id}$.

${ }^{57}$ See Radford, supra note 31, at 110.

${ }^{58} \mathrm{Id}$.

${ }^{59} \mathrm{Id}$.

${ }^{60}$ SCHWARTZ, supra note 33, at 167.

${ }^{61} \mathrm{Id}$.

${ }^{62} \mathrm{Id}$.

${ }^{63} \mathrm{Id}$.

${ }^{64} \mathrm{Id}$.
}

Pitt Tax Review | ISSN 1932-1821 (print) 1932-1996 (online) DOI 10.5195/taxreview.2019.101 | http://taxreview.law.pitt.edu 
loan programs. ${ }^{65}$ Meanwhile, these home loans were not available to racial and ethnic minorities because of discriminatory policies embedded in the programs ${ }^{66}$ As a result, PHA tenants were comprised of society's poorest. ${ }^{67}$ The median income of public housing residents fell from $57 \%$ of the national median in 1950 to $41 \%$ in 1960 , to $29 \%$ in 1970 , and to less than $20 \%$ by the mid-1990s ${ }^{68}$ As tenants became poorer, PHAs were receiving less money, while operational costs were increasing.

As the cost for maintaining public housing buildings increased and revenue received from rent decreased, federal subsidies became the main source of funding for public housing. ${ }^{69}$ The operational costs increased rapidly and the rent pool decreased as tenants became poorer. ${ }^{70}$ Some local agencies responded by charging higher rents that were unaffordable to many residents. ${ }^{71}$ The federal government placed a cap on rents and began directly subsidizing operational costs as well as capital costs. ${ }^{72}$ Public housing came to a standstill because it strongly relied on limited taxpayer dollars. ${ }^{73}$

${ }^{65}$ Kevin Fox Gotham, Racialization and the State: The Housing Act of 1934 and the Creation of the Federal Housing Administration, 43 SOC. PERSP. 291, 309-10 (2000).

${ }^{66}$ Id.; see also Alexis C. Madrigal, The Racist Housing Policy that Made Your Neighborhood, THE ATLANTIC (May 22, 2014), https://www.theatlantic.com/business/archive/2014/05/the-racist-housingpolicy-that-made-your-neighborhood/371439/ (discussing how "the FHA explicitly refused to back loans to black people or even other people who lived near black people").

${ }^{67}$ SCHWARTZ, supra note 33, at 168.

${ }^{68} \mathrm{Id}$.

${ }^{69} I d$. at 177.

${ }^{70} \mathrm{Id}$.

${ }^{71}$ Jaime Alison Lee, Rights at Risk in Privatized Public Housing, 50 Tulsa L. Rev. 759, 764 (2015). At the national level, even Secretary of Housing and Urban Development Ben Carson proposed to triple public housing rent. Hannah Natanson, Ben Carson Says He's Raising Rents to Put Poor Americans to Work. But in the District, the Majority Are Either Elderly, Disabled or Already at Work., WASH. POST (July 13, 2018), https://www.washingtonpost.com/local/social-issues/ben-carson-says-hesraising-rents-to-put-poor-americans-to-work--but-in-the-district-the-majority-are-either-elderly-ordisabled-or-already-work/2018/07/13/b85866a0-8127-11e8-b658-4f4d2a1 aeef1_story.html?utm_term= $.13179 \mathrm{a} 2073 \mathrm{e} 8$.

${ }^{72}$ Lee, supra note 71 , at 764 .

${ }^{73} \mathrm{Id}$.

Pitt Tax Review | ISSN 1932-1821 (print) 1932-1996 (online) DOI 10.5195/taxreview.2019.101 | http://taxreview.law.pitt.edu 


\section{6 | Pittsburgh Tax Review | Vol. 162019}

\section{Cheap Build with a Short Sight}

The minimal financial support the federal government initially provided resulted in higher future operational costs for PHAs. ${ }^{74}$ The reason for this minimal financial support is due to the fact that Congress placed a cap on the amount of federal funding that could be spent on building public housing. ${ }^{75}$ The 1937 Fair Housing Act set a maximum of $\$ 5,000$ per unit or $\$ 1,250$ per room in cities with a population of at least 500,000 and $\$ 4,000$ per unit or $\$ 1,000$ per room elsewhere. ${ }^{76}$ Proponents of private real estate interests viewed public housing as a threat to their businesses. ${ }^{77}$ In order to quickly respond to the mass poverty of the $1930 \mathrm{~s}$, public housing advocates compromised and agreed to spend below the federal maximum. ${ }^{78}$ An average of thirty percent below the maximum was spent on public housing units during that time..$^{79}$ Because of this reduced funding, many of the projects were built in a manner that was not durable. ${ }^{80}$ These public housing buildings contained a bare minimum of amenities: "closets were shallow and without doors, plaster walls were eschewed for cinderblocks. In many high-rise projects, elevators skipped every other floor; buildings lacked enclosed lobbies. Common spaces were kept to a bare minimum."

Cheap construction, however, resulted in abnormally high maintenance costs that could not be recouped via rental income. ${ }^{82}$ Now many PHAs are either in debt or cities simply elected to destroy their public housing buildings instead of maintaining them. ${ }^{83}$

\footnotetext{
${ }^{74}$ See id.

${ }^{75}$ SCHWARTZ, supra note 33, at 172.

${ }^{76} \mathrm{Id}$.

${ }^{77}$ See Radford, supra note 31, at 110.

${ }^{78} \mathrm{Id}$. at 112.

${ }^{79}$ Id. at $112-13$.

${ }^{80}$ See id.

${ }^{81} I d$. at 113.

${ }^{82} \mathrm{Id}$.

${ }^{83} \mathrm{Id}$.
}

Pitt Tax Review | ISSN 1932-1821 (print) 1932-1996 (online) DOI 10.5195/taxreview.2019.101 | http://taxreview.law.pitt.edu 


\section{Racial Discrimination}

The United States racially discriminated against minorities in public housing. ${ }^{84}$ The housing agencies kept races separate by building public housing for whites and different public housing for blacks. ${ }^{85}$ The Housing Act of 1949 continued the building of public housing and introduced slum clearance, which was formally known as urban redevelopment. ${ }^{86}$ Urban redevelopment aimed to renovate cities by demolishing dilapidated houses and building parks, new houses, and roads. ${ }^{87}$ The Housing Act of 1949 provided loans for slum clearance. ${ }^{88}$ Deteriorating buildings were supposed to be replaced, but this was not commonly practiced because localities had the option of switching to commercial development. ${ }^{89}$

Local municipalities used urban redevelopment to clear black slums and then moved some blacks into "high-rise, high density public housing." 90 However, through this process, many people who were displaced were not rehoused. ${ }^{91}$ The Housing Act of $1954^{92}$ reinstituted urban redevelopment under the guise of "urban renewal. ${ }^{.93}$ The slum clearance got worse. ${ }^{94}$ Local authorities often cleared slums without offering alternative living

${ }^{84}$ John I. Stewart, Jr., Comment, Racial Discrimination in Public Housing: Rights and Remedies, 41 U. CHI. L. REV. 582, 582 (1974).

${ }^{85}$ See generally Mittie Olion Chandler, Public Housing Desegregation: What Are the Options?, 3 HOUSING POL'Y DEBATE 509 (2010)

${ }^{86}$ Housing Act of 1949, Pub. L. No. 81-171, 63 Stat. 413; see also SCHWARTZ, supra note 33, at 164 (showing that due to World War I, public housing was put on an approximately fifteen-year hiatus).

${ }^{87}$ Housing Act of $1949 \S 110,63$ Stat. at 420.

${ }^{88}$ BruCe F. Berg, New York City POLITICS: GOVERning Gotham 93 (2007).

${ }^{89} \mathrm{Id}$. at 93 .

${ }^{90}$ See id. at 92 .

${ }^{91}$ See id. at 93 ("While the hope was that for every deteriorating housing unit cleared, a new unit of low- or moderate-income housing would be built to replace it, this did not occur.").

${ }^{92}$ Housing Act of 1954, Pub. L. No. 83-560, 68 Stat. 590 (1954).

${ }^{93}$ Alexander Von Hoffman, The Lost History of Urban Renewal, J. URBANISM 282 (2008).

${ }^{94} \mathrm{Id}$.

Pitt Tax Review | ISSN 1932-1821 (print) 1932-1996 (online) DOI 10.5195/taxreview.2019.101 | http://taxreview.law.pitt.edu 


\section{8 |Pittsburgh Tax Review | Vol. 162019}

arrangements or they rehoused inhabitants in high-rise public housing projects, which are considered ghettos today. ${ }^{95}$

These high-rise buildings were built for minorities. General Grant Houses (Grant Houses), located uptown in Morningside Heights of New York City near Columbia University, is a historic example of a public housing project that was built on a racial foundation. ${ }^{96}$ Grant Houses were built in $1957 .{ }^{97}$ One of the reasons why Grant Houses were built was to dissolve racial boundaries in the neighborhood. ${ }^{98}$ However, Columbia University used the Housing Act of 1949 to structure how the area of Morningside Heights would look. ${ }^{99}$ Morningside Heights was going through a racial transformation; black people moved to the northern edge of Morningside Heights from Harlem and Puerto Ricans were moving to the southern part of Morningside Heights. ${ }^{100}$ Columbia University was concerned that the area would become blighted. ${ }^{101}$

Grant Houses served as a means to block off Harlem from Morningside Heights. ${ }^{102}$ The project stretched from West 123rd street to West 133rd street. ${ }^{103}$ Within the process of building Grant Houses, 36,000 people were displaced because they could not conform to the area's plan. ${ }^{104}$ After the construction, the area became too expensive for low-income people. ${ }^{105}$ The

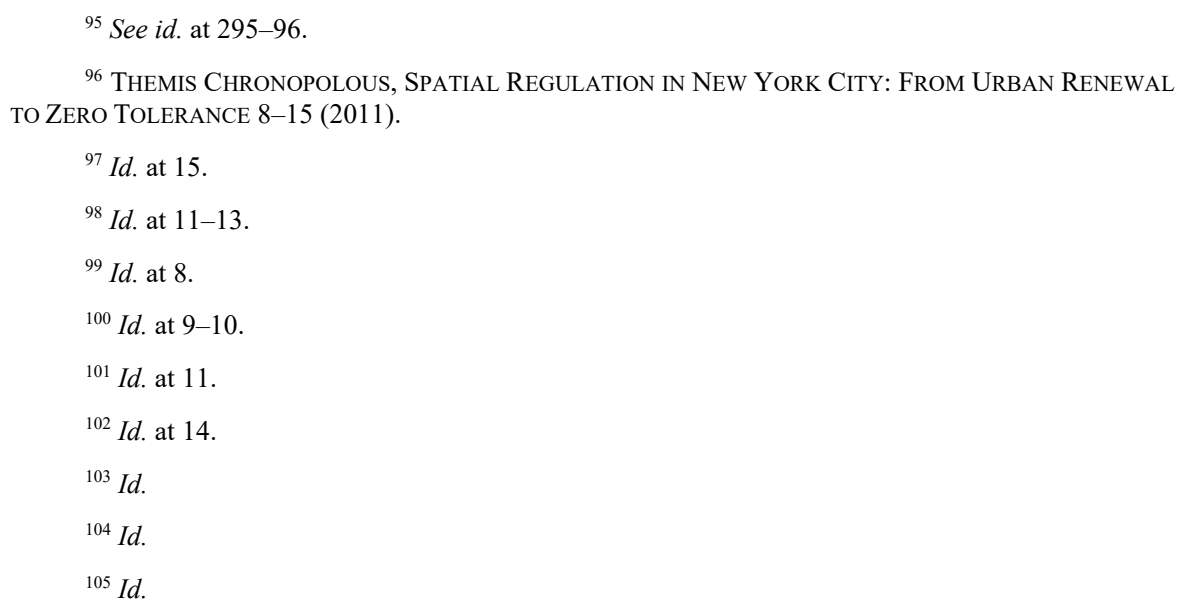

Pitt Tax Review | ISSN 1932-1821 (print) 1932-1996 (online) DOI 10.5195/taxreview.2019.101 | http://taxreview.law.pitt.edu 
building of the new Grant Houses did not create enough units to replace all the minorities they displaced. ${ }^{106}$

Moreover, statistics demonstrate that there is a racial divide by income. In $2010,66 \%$ of the residents were not white. ${ }^{107}$ In public housing located in high poverty areas: $41 \%$ percent are black, $40 \%$ are Hispanic, and $10 \%$ are white. ${ }^{108}$

\section{PRIVATE-PubliC AgREEMENT}

Between 1937 and the 1970s, public housing was the primary vehicle through which the federal government provided affordable housing to lowincome families. Starting in the 1970s, many cities began removing their high-rise public housing buildings and replacing them with programs that relied entirely on the private market. ${ }^{109}$ The U.S. Department of Housing and Urban Development (HUD) stated that \$26 billion was needed to repair the nation's aging public housing buildings after years of mismanagement. ${ }^{110}$ From a policy standpoint, it appeared the best solution was to remove government subsidized housing and to transition to utilizing the private sector with Section 8 housing vouchers and, later, the LIHTC program. ${ }^{11}$

\section{${ }^{106} I d$.}

${ }^{107}$ NAT'L LOW INCOME Hous. COAL., Housing SpOtLIGHT: WHO LiVES IN FEDERALLY ASSISTED HOUSING? 3 (2012), https://nlihc.org/sites/default/files/HousingSpotlight2-2.pdf.

${ }^{108} \mathrm{Id}$.

${ }^{109}$ See 24 C.F.R. § 971.7(b) (2006); see also Stephanie Garlock, By 2011, Atlanta Had Demolished All of Its Public Housing Projects. Where Did All Those People Go?, CiTYLAB (May 8, 2014), https://www.citylab.com/equity/2014/05/2011-atlanta-had-demolished-all-its-public-housing-projectswhere-did-all-those-people-go/9044/ (discussing the removal of project housing in Atlanta).

${ }^{110}$ U.S. Dep'T of Hous. \& URBAn DeV., RENTAL AsSistance Demonstration (RAD): ToOLKiT \#1: Why RAD? A RENTAL ASSISTANCE DEMONSTRATION (RAD) OVERVIEW 1 (2013), https://www.hud .gov/sites/documents/TOOLKIT1WHYRAD.PDF.

${ }^{111}$ See infra Part III.B.

Pitt Tax Review | ISSN 1932-1821 (print) 1932-1996 (online) DOI 10.5195/taxreview.2019.101 | http://taxreview.law.pitt.edu 


\section{A. Section 8}

The Housing Voucher Program, commonly referred to as Section 8, allows a person to find publicly subsidized housing in the private market. ${ }^{112}$ The voucher recipient is generally required to pay approximately thirty percent of their adjusted monthly income toward rent and utilities and the voucher would pay the remaining rent. ${ }^{113}$ These vouchers were envisioned as a way "for poor urban minorities to escape the social ills of the city and move to the suburbs." 114 As opposed to uprooting blacks and placing them in highrise, project-based housing, housing vouchers were intended to allow recipients to leave inner cities by finding a home in the suburbs. ${ }^{115}$

\section{B. Low-Income Housing Tax Credits}

As a matter of policy, Congress has encouraged the private market to provide affordable housing with the assistance of federal subsidies. ${ }^{116}$ Congress stated that "it is the policy of the United States to encourage the widest possible participation by private enterprise in the provision of housing for low or moderate income families." $" 117$ Accordingly, Congress created the LIHTC program to encourage developer and private investor involvement in the creation of low-income housing rental units. ${ }^{118}$

Through the LIHTC program, the government trades tax credits for temporary affordable housing units. ${ }^{119}$ LIHTC housing, however, bases the

112 Many believed that housing vouchers open the door for people to move into better neighborhoods, which will avail those people to better jobs and education. See BRUCE KATZ ET AL.,

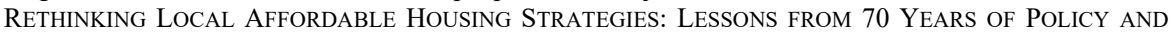
PRACTICE 32 (2003), https://www.brookings.edu/wp-content/uploads/2016/06/housingreview.pdf.

${ }^{113}$ See 42 U.S.C. $\S 1437 \mathrm{f}(\mathrm{o})(2)$ (2012). The Section 8 low-income housing program comes in two different forms - the voucher program and the project-based Section 8 - which are managed by housing authorities. Ctr. on Budget \& Policy Priorities, Section 8 Project-Based Rental Assistance 2 (2017), https://www.cbpp.org/sites/default/files/atoms/files/PolicyBasics-housing-1-25-13PBRA.pdf. The project-based Section 8 program is a rental subsidy that is attached to a particular apartment in a house that is privately owned. Id. Under the Housing Voucher Program, the government provides lowincome family recipients with a portable rental subsidy. See 42 U.S.C. $\$ 1437 f(0)(2)$, (r).

${ }^{114}$ These vouchers, however, are not perfect. It is difficult to find a landlord willing to participate. Kate Giammarise, For Those with Section 8 Vouchers, Finding Suitable Housing Difficult, PITTSBURGH POST-GAZETTE (June 20, 2016, 12:00 AM), http://www.post-gazette.com/local/city/2016/06/20/ Millions-in-Pittsburgh-housing-voucher-funding-not-going-to-vouchers/stories/201605060194

(discussing how voucher recipients are losing vouchers because they cannot find landlords). The Housing Vouchers are underutilized. Id. (discussing how in 2013, the City of Pittsburgh underused 1,500 to 2,000

Pitt Tax Review | ISSN 1932-1821 (print) 1932-1996 (online)

DOI 10.5195/taxreview.2019.101 | http://taxreview.law.pitt.edu 
rent on objective needs and not subjective needs. ${ }^{120}$ Specifically, PHAs calculate the rent based on a local area's median income in which the project is located rather than adjusting it to affordable based on a tenant's actual income. ${ }^{121}$ To qualify for the credits, a developer must submit an application to its respective state housing authority. ${ }^{122}$ In that application, the developer must provide a "qualified low-income housing project," which must qualify under one of three income-based tests. ${ }^{123}$ The first test, called the 20-50 Test, is if at least $20 \%$ of the units are occupied by individuals who make no more than $50 \%$ of AMI. ${ }^{124}$ The second test, known as the $40-60$ Test, is if at least $40 \%$ of the units are occupied by individuals who make no more than $60 \%$ of AMI. ${ }^{125}$ The third test, referred to as the Income Averaging Test, was added by Congress in 2018 and it allows applicants to average the income of tenants: the test is satisfied if at least $40 \%$ of tenants have an average income

vouchers). See National and State Housing Fact Sheets \& Data, CTR. ON BUDGET \& POLICY PRIORITIES, https://www.cbpp.org/research/housing/national-and-state-housing-fact-sheets-data (last updated Mar. 1, 2019 ) (showing that in 2016 , nationally only $89 \%$ of vouchers were used, New York City only used $88 \%$ of its vouchers, and Chicago only used $87.7 \%$ of vouchers).

${ }^{115}$ See J. Peter Byrne \& Michael Diamond, Affordable Housing, Land Tenure, and Urban Policy: The Matrix Revealed, 34 FORDHAM URB. L.J. 527, 538 (2007). It was easier to use already existing housing to implement low-income housing with housing vouchers than to build a whole new project building. Many communities opposed having such low-income housing in their "backyard." OFFICE OF Policy DeV. \& Research, U.S. DeP'T OF Hous. \& URBAn DeV., "Why Not In OuR COMMUnity?" REMOVING BARRIERS TO AFFORDABLE HOUSING 3 (2005), https://www.huduser.gov/portal/Publications/ wnioc.pdf (described as "NIMBY," not in my backyard syndrome).

${ }^{116}$ Housing and Urban Development Act of 1968, Pub. L. No. 90-448, § 901, 82 Stat. 476, 547.

${ }^{117} I d$.

${ }^{118} I d$.

${ }^{119}$ Treas. Reg. § 1.42-1T(a)(2) (as amended in 2004); see also I.R.C. § 42(b)(1)-(2), (m).

${ }^{120}$ See Treas. Reg. § 1.42-1T(a)(2).

${ }^{121} I d$.

${ }^{122} I d . \S 1.42-1 \mathrm{~T}(\mathrm{~d})(8)(\mathrm{i})$.

${ }^{123}$ I.R.C. $\S 42(\mathrm{c})(2)$. Private developers seeking to be allocated credits will make a proposal and submit it to their respective HCA. Treas. Reg. § 1.42-1T(a)(2). The HCA will then make a decision based on which proposal scored the highest.

${ }^{124}$ I.R.C. $\S 42(\mathrm{~g})(1)(\mathrm{A})$.

${ }^{125} I d . \S 42(\mathrm{~g})(1)(\mathrm{B})$.

Pitt Tax Review | ISSN 1932-1821 (print) 1932-1996 (online) DOI 10.5195/taxreview.2019.101 | http://taxreview.law.pitt.edu 
of no more than $60 \%$ of AMI so long as no tenant has income of more than $80 \%$ of AMI. ${ }^{126}$

LIHTC provides two different levels of tax benefits. ${ }^{127}$ The tax benefits can be for either $30 \%(4 \% \text { credit })^{128}$ or, more competitively, $70 \%(9 \%$ credit ${ }^{129}$ of the eligible costs of a low-income housing project. ${ }^{130}$ Both the $4 \%$ and $9 \%$ credit benefits are distributed over a ten-year period. ${ }^{131}$ In return, the developer has to ensure affordable housing units for a minimum of fifteen years. ${ }^{132}$ The following is an example of LIHTC tax benefits:

Consider a new affordable housing apartment complex with a qualified basis of $\$ 1$ million. Since the project involves new construction it will qualify for the $9 \%$ credit and generate a stream of tax credits equal to $\$ 90,000$ ( $9 \%$ x $\$ 1$ million) per year for 10 years, or $\$ 900,000$ in total. Under the appropriate interest rate the present value of $\$ 900,000$ stream of tax credits should be equal to $\$ 700,000$, resulting in $70 \%$ subsidy. The subsidy is intended to incentivize the development of affordable housing that otherwise may not be financially feasible or attractive to alternative investments. ${ }^{133}$

The Internal Revenue Service (IRS) allocates the federal tax credits to state housing credit agencies (HCAs) based on each state's population. ${ }^{134}$ The HCAs are responsible for directly allocating the credits to private

${ }^{126}$ Mark P. Keightley, Cong. Research SerV., RS22389, An Introduction to the LowINCOME HOUSING TAX CREDIT 3 (2019), https://fas.org/sgp/crs/misc/RS22389.pdf.

${ }^{127}$ I.R.C. $\S 42(b)(1)(B)$.

${ }^{128} I d . \S 42(\mathrm{~b})(1)(\mathrm{B})(\mathrm{ii})$.

${ }^{129} \mathrm{Id}$. $\$ 42(\mathrm{~b})(1)(\mathrm{B})(\mathrm{i})$. Even though they are referred to as the $4 \%$ and $9 \%$ credits, the amount of the credit varies based on whatever amount gets them to $30 \%$ or $70 \%$. See KEIGHTLEY, supra note 126 , at 1 .

${ }^{130}$ I.R.C. $\S 42(b)(1)(B)(i) .4 \%$ and $9 \%$ is the way the $30 \%$ and $70 \%$ tax credits are referred to in practice. KEIGHTLEY, supra note 126 , at 1 . It means that "[e]ach year, for 10 years, a tax credit equal to roughly $4 \%$ or $9 \%$ of a project's qualified basis (cost of construction) is claimed." Id. $4 \%$ and $9 \%$ is just a faster way to calculate how much a developer is receiving over the ten year period.

${ }^{131} I d . \S 42(\mathrm{f})(1)$.

${ }^{132} I d$. $\S \S 42(\mathrm{i})(1),(\mathrm{j})(1)$. If the project fails to comply with the LIHTC rules during the 15 -year compliance period, the IRS can recapture credits. Id.

${ }^{133}$ KeIGHTLEY, supra note 126 , at 1-2.

${ }^{134}$ I.R.C. $§ 42(h)(3)$.

Pitt Tax Review | ISSN 1932-1821 (print) 1932-1996 (online)

DOI 10.5195/taxreview.2019.101 | http://taxreview.law.pitt.edu 
developers. ${ }^{135}$ Based on the required federal "selection criteria," 136 each HCA creates their own "Qualified Allocation Plan" (QAP) ${ }^{137}$ in keeping with the state's priorities for the desired type, location, and ownership of affordable housing. ${ }^{138}$ QAPs vary because each state has freedom in structuring their allocation process and each state also has its own unique housing needs. ${ }^{139}$ Most HCAs apply a scoring system in which a proposal will need or require a specific amount of points to satisfy a category. ${ }^{140}$

There is an increased credit for "qualified census tracts"141 (QCTs) and "difficult development areas" 142 (DDAs). In addition, § 42(m)(1)(B)(ii) of the Code requires HCAs to create a QAP that gives a preference to:

1. "[P]rojects serving the lowest income tenants."

2. "[P]rojects obligated to serve qualified tenants for the longest periods." 144

3. " $[\mathrm{P}]$ rojects which are located in a qualified census tract ... and the development of which contributes to a concerted community revitalization plan."

${ }^{135} I d . \S 42(\mathrm{~m})(1)(\mathrm{A})(\mathrm{i})$.

${ }^{136} I d . \S 42(\mathrm{~m})(1)(\mathrm{C})$.

${ }^{137} \mathrm{Id}$. $442(\mathrm{~m})(1)(\mathrm{B})$.

${ }^{138} I d$. $\S 42(\mathrm{~m})(1)(\mathrm{C})$. HCAs must annually submit a QAP explaining how the credits will be evaluated. See id. § 42(m)(1)(B)(iii).

${ }^{139}$ See id. $\S 42(\mathrm{~m})(1)(\mathrm{B})(\mathrm{i})$.

${ }^{140}$ The Code provides some examples of factors such as project location, housing needs, sponsor characteristics, and public housing waitlist. See id. $\S 42(\mathrm{~m})(1)(\mathrm{C})$.

${ }^{141} I d . \S 42(\mathrm{~m})(1)(\mathrm{B})$.

${ }^{142} I d . \S 42(\mathrm{~d})(5)(\mathrm{iii})(\mathrm{I})$.

${ }^{143} I d . \S 42(\mathrm{~m})(\mathrm{B})(\mathrm{ii})(\mathrm{I})$.

${ }^{144} I d . \S 42(\mathrm{~m})(\mathrm{B})(\mathrm{ii})(\mathrm{II})$.

${ }^{145} \mathrm{Id}$. $\$ 42(\mathrm{~m})(\mathrm{B})(\mathrm{ii})(\mathrm{III})$.

Pitt Tax Review | ISSN 1932-1821 (print) 1932-1996 (online) DOI 10.5195/taxreview.2019.101 | http://taxreview.law.pitt.edu 
A QCT is a location in which "50 percent or more of the households have an income which is less than 60 percent of the area median income," as designated by the Secretary of HUD. ${ }^{146}$

After a developer is successful in this competitive application process, the developer has two options: it can directly claim the tax benefits on its income tax return, or it can sell the tax credits to private investors. ${ }^{147}$ If the developer chooses to sell the credits, it can raise hard money to finance the construction expense rather than taking out a loan to finance the construction costs. ${ }^{148}$ The price of these credits depends entirely on supply, demand, and risk assessments. ${ }^{149}$

\section{AFFIRMATIVELY FURTHER FAIR HOUSING AND PRIVATIZATION}

The Fair Housing Act of 1968 was created to respond to the history of explicit racial housing discrimination in rental and the sale of houses. ${ }^{150}$ This legislation placed a duty on HUD entities and all other agencies involved in

${ }^{146} I d . \S 42(\mathrm{~d})(5)(\mathrm{B})(\mathrm{ii})(\mathrm{I})$.

${ }^{147} I d$. $\S 42(\mathrm{~b})(1)$ ("'The percentages prescribed by the Secretary for any month shall be percentages which will yield over a 10-year period ...."); see Sarah Pickering, Note, Our House: Crowdfunding Affordable Homes with Tax Credit Investment Partnerships, 33 REV. BANKING \& FIN. L. 937, 951-52 (2014) (discussing the actual process for how tax credits are sold).

${ }^{148}$ Id. at $946-47$.

${ }^{149}$ The prices for the credits have fluctuated depending on a variety of factors. In 2016, the tax credits were reportedly sold for over $\$ 1.00$ each. Donna Kimura, LIHTC Prices Climb and Climb: Syndicators Report First-Half Results, Look Ahead to Rest of 2016, AfFORDABLE Hous. Fin. (Aug. 16, 2016), http://www.housingfinance.com/finance/lihtc-prices-climb-and-climb; see also LIHTC Pricing Trends, NOVOGRADAC, https://www.novoco.com/resource-centers/affordable-housing-tax-credits/ data-tools/lihtc-pricing-trends (last visited Apr. 7, 2019). In 2008, the tax credit value decreased substantially. See Tom Daykin, Dropping Demand for Tax Credits Hits Apartment Projects, MILWAUKEE J. SENTINEL (Dec. 16, 2009), http://archive.jsonline.com/newswatch/79342762.html; see also KeIGHTLEY, supra note 126, at 5 (showing the Tax Cuts and Jobs Act is anticipated to decrease the value of the credits).

${ }^{150}$ Federal law recognizes that people should not be limited in living opportunities on account of race. See, e.g., Shelly v. Kraemer, 334 U.S. 1 (1948); see also 42 U.S.C. § 3608(d) (2012) (“All executive departments and agencies shall administer their programs and activities relating to housing and urban development (including any Federal agency having regulatory or supervisory authority over financial institutions) in a manner affirmatively to further the purposes of this subchapter and shall cooperate with the Secretary to further such purposes."); Shannon v. U.S. Dep't of Hous. \& Urban Dev., 436 F.2d 809, 821 (3d Cir. 1970) ("Increase or maintenance of racial concentration is prima facie likely to lead to urban blight and is thus prima facie at variance with ... national housing policy.").

Pitt Tax Review | ISSN 1932-1821 (print) 1932-1996 (online)

DOI 10.5195/taxreview.2019.101 | http://taxreview.law.pitt.edu 
the administration of housing policies to take proactive measures to advance racial integration. ${ }^{151}$ The ability of FHA to adequately address and remedy inequities in the provision of fair housing has been informed by, and at times delayed by, a series of cases addressing fair housing in Chicago that began before - and concluded decades after - the enactment of FHA. ${ }^{152}$ Beginning as a suit filed by a group of black public housing tenants against the Chicago Housing Authority, ${ }^{153}$ the Gautreaux litigation is important because the Supreme Court set the stage for how the duty to affirmatively further fair housing can be achieved. The results in Gautreaux were also informed by the holdings of two other cases: Shannon v. United States Department of Housing and Urban Development ${ }^{154}$ and Milliken v. Bradley. ${ }^{155}$ Ultimately, the outcome was that the private sector can be used to provide fair housing.

\section{A. Gautreaux Overview}

In Gautreaux, a group of black public housing residents (Plaintiffs) claimed that HUD and the Chicago Housing Authority's (CHA) tenant selection and placement policies were unconstitutional because they intentionally located public housing at sites intended to maintain racial separation and neglected to select sites that would advance racial integration. ${ }^{156}$ The district court denied CHA's motion to dismiss, concluding that the Plaintiffs "[had] the right under the Fourteenth Amendment to have sites selected for public housing projects without regard to the racial composition of either the surrounding neighborhood or of the projects

15142 U.S.C. $\S \S 3601-3609$ (2012). “The duty to 'affirmatively further' fair housing . . [ [stems] partially [from the] resistance [to] HUD [policies] — which at the time was the primary federal source for affordable housing funds-[by] local housing authorities [who] built public housing projects anywhere other than in poor, racially segregated neighborhoods." Myron Orfield, Racial Integration and Community Revitalization: Applying the Fair Housing Act to the Low Income Housing Tax Credit, 58 VAND. L. REV. 1747, 1766-67, 1771 (2005). The Fair Housing Act of 1968 was created to directly undo harms caused by racial and social isolation. Id.

${ }^{152}$ Orfield, supra note 151, at 1771-73.

${ }^{153} \mathrm{Id}$.

${ }^{154} 436$ F.2d 809 (3d Cir. 1970).

${ }^{155} 418$ U.S. 717 (1974).

${ }^{156}$ Gautreaux v. Chicago Hous. Auth., 265 F. Supp. 582, 583 (N.D. Ill. 1967).

Pitt Tax Review | ISSN 1932-1821 (print) 1932-1996 (online)

DOI 10.5195/taxreview.2019.101 | http://taxreview.law.pitt.edu 
themselves." ${ }^{157}$ In 1969, the district court granted summary judgment in favor of the Plaintiffs. ${ }^{158}$ The court found that CHA violated both the Equal Protection Clause of the Fourteenth Amendment and pre-FHA civil rights acts ${ }^{159}$ by building public housing and using race to place tenants in those developments. ${ }^{160}$ The Court reached this conclusion based on uncontested evidence demonstrating that the public housing system was racially segregated: four of the duplexes had a majority of white residents and were located in white suburbs, while the rest of the units had a majority of black residents and were located in black neighborhoods. ${ }^{161}$

In the appeal of a companion lawsuit against HUD, the Seventh Circuit found HUD was also liable for knowingly assisting in racially discriminatory public housing practices by restricting access to financial assistance. ${ }^{162}$ When this reached the Seventh Circuit, FHA had been enacted, Shannon was in the courts, and the lower courts were discussing the duty to affirmatively further fair housing. ${ }^{163}$ Shannon is particularly important because the court held that HUD must take racial and socioeconomic data into consideration in housing plans to affirmatively further fair housing, and then later deemed a color-

$$
\begin{aligned}
& { }^{157} I d . \\
& { }^{158} I d .
\end{aligned}
$$

${ }^{159}$ Gautreaux v. Chicago Hous. Auth., 296 F. Supp. 907, 913-14 (N.D. Ill. 1969) (filed prior to FHA enactment). See generally 42 U.S.C. $\S \S 1981,1983$ (2012).

${ }^{160}$ Gautreaux, 296 F. Supp. at 913-14.

${ }^{161}$ Hills v. Gautreaux, 425 U.S. 284, 288 (1976).

${ }^{162}$ Gautreaux v. Romney, 448 F.2d 731, 733 (7th Cir. 1971).

${ }^{163}$ Orfield, supra note 151, at 1771. In Shannon, black and white residents claimed that planned public housing was being located in areas with high concentrations of poverty and would further concentrate poor black tenants, which would lead to resegregation. Shannon v. U.S. Dep't of Hous. \& Urban Dev., 436 F.2d 809, 811-12 (3d Cir. 1970). The Court held that HUD had a duty to further fair housing. Id. at 816 . Furthermore, the court clarified that FHA bars HUD from funding a project that further segregates a neighborhood. $I d$. at 820 . The court clarified that HUD must take racial and socioeconomic data into consideration in planned housing, and noted that a color-blind approach would be impermissible. Id. at 820-21. Although the court gave HUD discretion to determine how to consider such factors, the court suggested that HUD should consider the racial and economic demographics of a neighborhood, school quality, and past and current practices of local authorities. Id. at 19. The court also provides the following dicta which nullifies that duty: "[The court is not] suggesting that desegregation of housing is the only goal of the national housing policy. There will be instances where a pressing case may be made for rebuilding of a racial ghetto." Id. at 822. Shannon was adopted in other opinions. See generally NAACP v. Sec'y of Hous. \& Urban Dev., 817 F.2d 149, 154 (1st Cir. 1987) (stating that Title VIII imposes a duty on HUD that is more than simply refraining from discrimination).

Pitt Tax Review | ISSN 1932-1821 (print) 1932-1996 (online)

DOI 10.5195/taxreview.2019.101 | http://taxreview.law.pitt.edu 
blind approach impermissible. ${ }^{164}$ In Gautreaux, the Seventh Circuit discussed segregation as a pressing concern in Chicago. ${ }^{165}$ The Seventh Circuit stated white flight and black concentration are "the most serious domestic problem[s] facing America today." 166

The Seventh Circuit further affirmed the implementation of a "comprehensive plan." 167 This plan guided placing some of the new public housing units in the suburbs outside of Chicago, even though the discrimination took place within the geographical boundaries of the City of Chicago. ${ }^{168}$ On appeal to the Supreme Court, both HUD and CHA again argued that the ruling in Milliken would bar implementation of a comprehensive plan as a remedy. ${ }^{169}$

In Milliken, the Supreme Court reversed the Sixth Circuit's approval of metropolitan-wide relief in school desegregation (Milliken Plan). ${ }^{170}$ The Milliken Plan would have required fifty-four schools in Detroit's metropolitan area to consolidate in a manner that would remedy racial discrimination in the operation of the public schooling system. ${ }^{171}$ Unlike Milliken, the Supreme Court in Gautreaux first noted that HUD and CHA clearly violated the Constitution. ${ }^{172}$ Because of this violation, HUD and CHA were required to formulate a solution that would provide the greatest possible degree of relief. ${ }^{173}$ Second, the Supreme Court further stated that " $[t]$ he

\footnotetext{
${ }^{164}$ Shannon, 436 F.2d. at 821.

${ }^{165}$ Gautreaux v. Chicago Hous. Auth., 503 F.2d 930, 938-39 (7th Cir. 1974).

${ }^{166} I d$. at 938 .

${ }^{167}$ Id. at 936.

${ }^{168} \mathrm{Id}$.

${ }^{169}$ Hills v. Gautreaux, 425 U.S. 284, 291-92 (1976).

${ }^{170}$ Milliken v. Bradley, 418 U.S. 717, 745 (1974). In Gautreaux, 503 F.2d at 935-36, the Seventh Circuit found that Milliken was distinguishable from public housing in Chicago. Unlike local schools, public housing was not "deeply rooted [in the] tradition of local control; rather, public housing is a federally supervised program with early roots in federal statutes." Id. Housing discrimination had been prohibited for more than a century, by federal law. Id.

${ }^{171}$ Milliken, 418 U.S. at $722-23$.

${ }^{172}$ Gautreaux, 425 U.S. at 296.

${ }^{173}$ Id. at 299.
}

Pitt Tax Review | ISSN 1932-1821 (print) 1932-1996 (online) DOI 10.5195/taxreview.2019.101 | http://taxreview.law.pitt.edu 
relevant geographic area for purposes of the respondents housing option is the Chicago Housing Market and not the Chicago City limits." 174 The Supreme Court, in affirming the lower court's Gautreaux remedy, declared that the metropolitan area remedy must be "consistent with and supportive of" federal housing policy, including the duty to affirmatively further fair housing. ${ }^{175}$

In 1981, about fifteen years after the original suit, these decisions led to a metropolitan consent decree between HUD and the Plaintiffs. ${ }^{176}$ The consent decree created Gautreaux Assisted Housing Program (GAHP) and divided Chicago into three areas: general (less than 30\% minority population), limited (30\% or more minority population), and revitalizing (areas with more than $30 \%$ minority populations that are undergoing redevelopment). ${ }^{177}$ The agreement involved the placement of up to 7100 persons in assisted units in the general and revitalized areas. ${ }^{178}$ GAHP also used Section 8 vouchers created by Congress in $1974 .{ }^{179}$

\section{B. Saga of the Gautreaux Remedy}

The Supreme Court's decision in Gautreaux supported reliance on the private market to mend the Housing Authority's past acts of discrimination. ${ }^{180}$ The Supreme Court's decision established the scope of

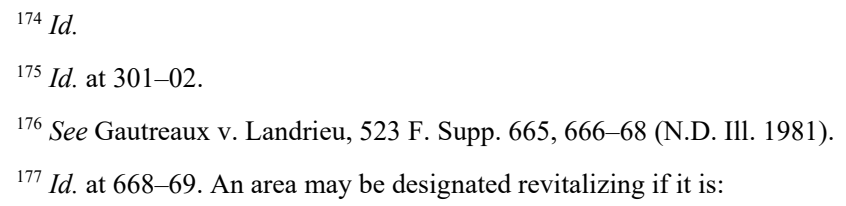

(1) undergoing visible redevelopment or evidences impending construction; (2) located along the lakefront; (3) scheduled to receive Community Development Block Grant Funds; (4) accessible to good transportation; (5) an area with a significant number of buildings already up to code standards; (6) accessible to good shopping; (7) located near attractive features, such as [a] lake or downtown; (8) free of an excessive concentration of assisted housing; (9) located in an area which is not entirely or predominantly in a minority area and (10) not densely populated.

Id. at 671 .

$$
\begin{aligned}
& { }^{178} I d . \\
& { }^{179} I d . \\
& { }^{180} \text { Gautreaux, } 425 \text { U.S. at } 301-02 .
\end{aligned}
$$

Pitt Tax Review | ISSN 1932-1821 (print) 1932-1996 (online) DOI 10.5195/taxreview.2019.101 | http://taxreview.law.pitt.edu 
relief by providing a framework for the method in which the lower district court and/or parties could resolve the issue of racial discrimination. ${ }^{181}$ The Court discussed two remedies: (1) the placement of public housing in areas that are consistent with the Fair Housing $\mathrm{Act}^{182}$ and (2) utilizing the private sector to build low-income housing with Section $8 .{ }^{183}$ Although the Court laid the groundwork for both a public and a private remedy, it appeared to regard the latter as the more enticing of the two options. ${ }^{184}$

In addressing the first option, using public housing in a way that furthers desegregation with the metropolitan-wide plan, the Court concluded that such relief could potentially be used. ${ }^{185}$ The opinion spent time explaining that such a remedy would be plausible and would not be contrary to any preceding case. ${ }^{186}$ But, most importantly, the Court did not conclude that the lower court was required to adopt the public housing plan and the Court devoted no more time to discussing that option. ${ }^{187}$

The Court then turned to discussing how the private sector could be used to reduce discrimination in public housing. ${ }^{188}$ The Court emphasized the changes that had taken place in federal low-income housing policy. ${ }^{189}$ Congress had just enacted the Section 8 Rent Subsidy Program in 1974 and relocated its funding dramatically from public housing programs and into the Section 8 Program. ${ }^{190}$ The Section 8 program was a move toward privatizing low-income housing. ${ }^{191}$

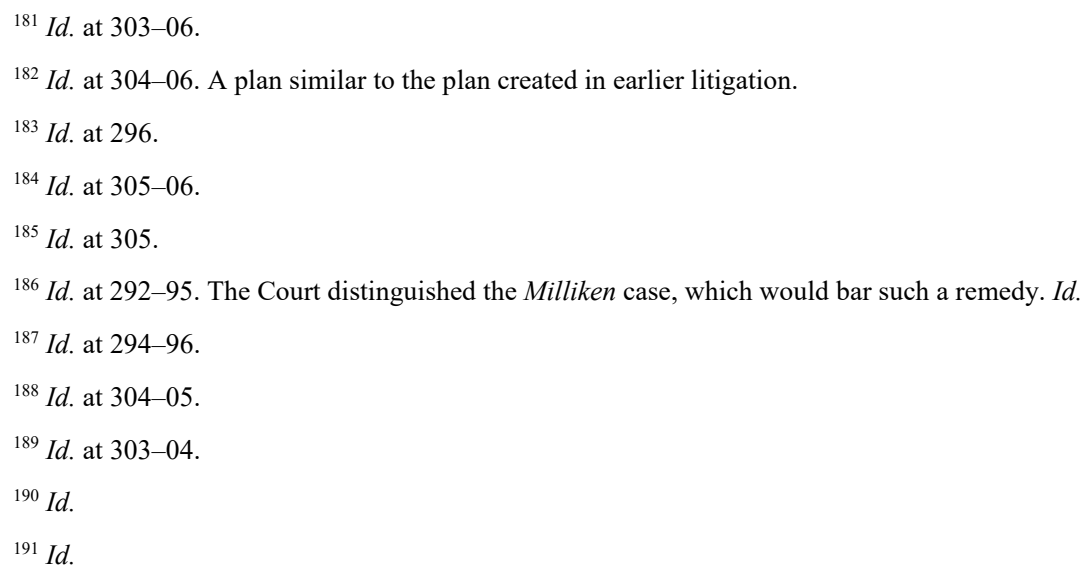




\section{0 |Pittsburgh Tax Review | Vol. 162019}

The Court embraced the private Section 8 approach and presented it as a better option for the lower court to consider as a remedy. ${ }^{192}$ The Court observed that the Section 8 program both enlarged HUD's role in "the creation of housing opportunities" and "largely replaced the older federal low-income housing programs." 193 As a result, many cities began removing their stock of public housing units. ${ }^{194}$ Section 8 was the central point of the Court's discussion. ${ }^{195}$ " [T] $]$ he Court's decision planted a seed that developed into a housing program for low-income Black families to move throughout the Chicago metropolitan area." 196 On remand, lawyers for the plaintiff and HUD arrived at an agreement that incorporated using the private market. ${ }^{197}$ They decided to use the Section 8 vouchers to distribute affordable housing fairly and followed the Supreme Court's lead in utilizing the private market. $^{198}$

\section{Section 8 Housing Vouchers and Implementation of Gautreaux Remedy}

In Gautreaux, the parties agreed to employ Section 8 as a remedy. ${ }^{199}$ The first placement of families in the suburbs was successful. ${ }^{200}$ In that group, HUD moved 4500 black families out of the inner city. ${ }^{201}$ A majority of them moved into suburban and predominantly white neighborhoods. ${ }^{202}$ These suburbs offered improved employment opportunities and a better

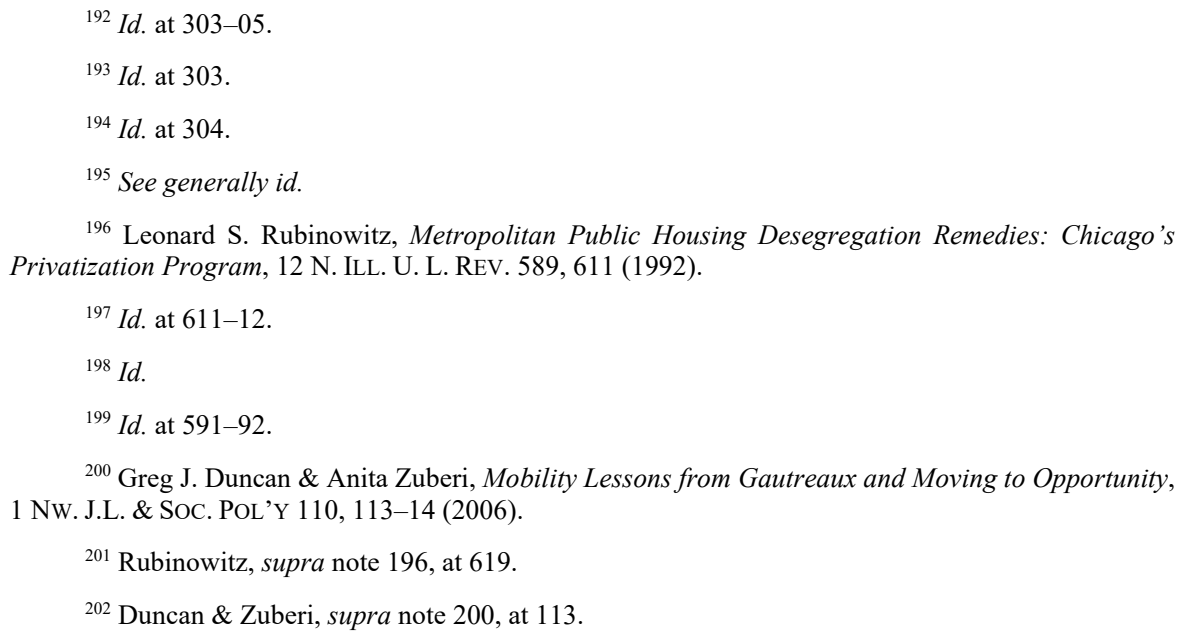

Pitt Tax Review | ISSN 1932-1821 (print) 1932-1996 (online) DOI 10.5195/taxreview.2019.101 | http://taxreview.law.pitt.edu 
education. ${ }^{203}$ Twenty-two years later, results showed intergenerational success and families were still living in neighborhoods with similar poverty rates. ${ }^{204}$ Children were more likely to graduate from high school, attend college, and go on to be employed. ${ }^{205}$

Also, the children placed in the suburbs with their mothers, who were old enough to live on their own in the 1990s, continued to reside in neighborhoods that had lower poverty rates and were more integrated than the ones that they originally lived in. ${ }^{206}$ Most of the families were moved from areas where the poverty rate was about $40 \%$ to areas with the poverty rate of about $16 \%{ }^{207}$ As of the late 1990 s, many of these families were living in similar poverty rate areas of about $18 \% .{ }^{208}$ In terms of neighborhood racial demographics, in the 1990s, these families remained in areas that were not predominantly black. ${ }^{209}$

However, the second set of families that were placed in suburbs did not experience similar results. ${ }^{210}$ These voucher holders moved to neighborhoods with poverty rates as low as $13 \%,{ }^{211}$ and about half of these voucher holders moved to neighborhoods with poverty rates of $27 \%{ }^{212}$ As a result of the Section 8 placements, the voucher holders transitioned originally from neighborhoods with a racial demographic of $80 \%$ black to $11 \%$ black. ${ }^{213}$ Half

\footnotetext{
${ }^{203}$ Id. at 116 .

${ }^{204} \mathrm{Id}$. at $113-14$

${ }^{205} \mathrm{Id}$.

${ }^{206} I d$.

${ }^{207} \mathrm{Id}$.

${ }^{208} I d$.

${ }^{209} I d$.

${ }^{210} I d$. at 114 . The Housing Authority of Chicago has been criticized for replacing vertical ghettos with horizontal ghettos. Steve Bogira, Separate, Unequal, and Ignored, CHI. READER (Feb. 10, 2011), https://www.chicagoreader.com/chicago/chicago-politics-segregation-african-american-black-whitehispanic-latino-population-census-community/Content?oid=3221712.

${ }^{211}$ See Duncan \& Zuberi, supra note 200, at 114.

${ }^{212} I d$.

${ }^{213}$ Id.
}

Pitt Tax Review | ISSN 1932-1821 (print) 1932-1996 (online) DOI 10.5195/taxreview.2019.101 | http://taxreview.law.pitt.edu 


\section{2 |Pittsburgh Tax Review |Vol. 162019}

of those that moved ultimately returned to predominantly black neighborhoods with average poverty rates of about $61 \%{ }^{214}$

Research on the voucher program at a national level reveals that Section 8 voucher recipients are not moving to better neighborhoods. ${ }^{215}$ Studies attribute the limitation of housing vouchers to local-market-level factors and individual families. ${ }^{216}$ At the local level, families encounter the tightness of the local housing market, spatial distribution of affordable housing, and discrimination in the housing market. ${ }^{217}$ At the individual family level, families may choose to stay in neighborhoods with concentrations of poverty or clusters of the same race. ${ }^{218}$ For example, a family may stay in a poor neighborhood because it is where they have established social networks. ${ }^{219}$ Despite this data, because Section 8 housing yielded some positive outcomes, Congress indicated that the private market might be the best solution for deciding how the federal government should enact affordable housing policy. $^{220}$

\section{TRANSFER OF DISCRIMINATION}

As foreshadowed by the Gautreaux remedy, the federal government has transitioned to reliance on the private sector to create affordable housing with LIHTC. ${ }^{221}$ Similar to the manner in which public housing was built in a way that perpetuated racial discrimination, LIHTC housing credits are being

${ }^{214} I d$.

${ }^{215}$ Sandra J. Newmann \& Ann B. Schnare, “. . . And a Suitable Living Environment”: The Failure of Housing Programs to Deliver on Neighborhood Quality, 8 Housing POL'Y DEBATE 703, 711 (1997); see also OfFice of Policy Dev. \& ReseArCh, U.S. DeP'T OF Hous. \& URBAN DeV., Housing ChOice VOUCHER LOCATION PATTERNS: IMPLICATIONS FOR PARTICIPANTS AND NEIGHBORHOOD WELFARE 33 (2003), https://www.huduser.gov/publications/pdf/location_paper.pdf.

${ }^{216}$ OfFICE OF POLICY DEV. \& ReSEARCH, supra note 215, at 33.

${ }^{217}$ Duncan \& Zuberi, supra note 200, at 114.

${ }^{218}$ Housing Choice Vouchers Fact Sheet, U.S. DeP’T Hous. \& URBAN DEV., https://www.hud.gov/ topics/housing_choice_voucher_program_section_8 (last visited Apr.15, 2019).

${ }^{219} \mathrm{Id}$.

${ }^{220}$ OfFICE OF POLICY DEV. \& RESEARCH, supra note 215 , at $85-86$.

${ }^{221} I d$.

Pitt Tax Review | ISSN 1932-1821 (print) 1932-1996 (online)

DOI 10.5195/taxreview.2019.101 | http://taxreview.law.pitt.edu 
distributed in a way that continues racial segregation. ${ }^{222}$ Because LIHTC is operated through the private market and because the Supreme Court in ICP allowed Housing Authorities (HAs) and private investors to legitimize placement decisions with a business purpose justification, HAs and private investors are insulated from fair housing mandates. ${ }^{223}$

\section{A. The LIHTC Approval Process Fails at Furthering Fair Housing}

As auspicious as the Court in Gautreaux may have discussed utilizing the private market to produce low-income housing, ${ }^{224}$ LIHTC is not furthering FHA fair housing goals based on a statutory interpretation. ${ }^{225}$ LIHTC prioritizes building units in QCTs, ${ }^{226}$ which are areas with high levels of poverty already in place. ${ }^{227}$ The preference for building in these QCTs leads developers to locate LIHTC-funded developments in a manner that maintains segregation. ${ }^{228}$

Between 1995 and 2009, there was a national increase in the percentage of credits being allocated in high-poverty QCTs. ${ }^{229}$ In 1995, 20.6\% of LIHTC projects were built in high-poverty qualified areas. ${ }^{230}$ By 2003, LIHTC projects built in QCTs accounted for $34.8 \%$ of all LIHTC developments. ${ }^{231}$

222 John Baber, Thank You Sir, May I Have Another: The Issue of the Unsustainability of Low Income Housing Tax Credits and Proposed Solutions, 4 U. BALT. J. LAND \& DEV. 39, 47-50 (2014).

${ }^{223}$ See discussion infra Part IV.A.

${ }^{224}$ See Hills v. Gautreaux, 425 U.S. 284, 303-04 (1976).

${ }^{225}$ See I.R.C. $\S 42(\mathrm{~d})(5)(\mathrm{B})(\mathrm{ii})(\mathrm{I})$.

${ }^{226} \mathrm{Id}$.

${ }^{227}$ See Office of Policy Dev. \& Research, Qualified Census Tracts and Difficult Development Areas, U.S. DEP'T OF Hous. \& URBAN DEV., https://www.huduser.gov/portal/datasets/qct.html (last visited Apr. 7, 2019).

${ }^{228}$ See Office of Policy Dev. \& Research, U.S. Dep’t of Hous. \& URban Dev., New LowIncome Housing TAX CRedit Property Data Available 6 (2011), https://www.huduser.gov/portal/ Datasets/lihtc/topica19509.pdf.

$$
\begin{aligned}
& { }^{229} I d . \\
& { }^{230} I d . \\
& { }^{231} I d .
\end{aligned}
$$

Pitt Tax Review | ISSN 1932-1821 (print) 1932-1996 (online) DOI 10.5195/taxreview.2019.101 | http://taxreview.law.pitt.edu 


\section{4 | Pittsburgh Tax Review | Vol. 162019}

The rate increased to $38.1 \%$ in $2009 .{ }^{232}$ According to a study done by the Fair Housing Justice Centre in New York, 77\% of the LIHTC units developed in New York City were located in minority neighborhoods and only $8 \%$ of lowincome units were developed in areas with more than $80 \%$ non-Hispanic whites. ${ }^{233}$ Furthermore, $70 \%$ of LIHTC housing units were approved in areas of either high or extreme poverty concentration, with more than half of the units in areas with extreme poverty. ${ }^{234}$

The IRS recognized that placing LIHTC projects in QCT's risks exacerbating concentrations of poverty. ${ }^{235}$ In an attempt to minimize these effects, the IRS issued Notice 2016-77, which states that a project will not qualify unless it is both located in a QCT and its development contributes to a "concerted community revitalization plan." 236 The notice also stated that the Department of Treasury did not provide a definition for "concerted community revitalization plan" for states to apply. ${ }^{237}$ Without further clarity from the IRS, HAs are forced to prioritize allocating the credits to sites in impoverished racial enclaves. ${ }^{238}$

\section{B. Inclusive Communities and the Changed Pleading Standard}

The discriminatory effects resulting from private-sector public housing programs are now more difficult to remedy because the Supreme Court has made it increasingly difficult for litigants making disparate impact claims that survive the pleading stages of litigation. ${ }^{239}$ On the one hand, in Inclusive

$$
\begin{aligned}
& { }^{232} \mathrm{Id} \text {. } \\
& { }^{233} \mathrm{Id} \text {. } \\
& { }^{234} \mathrm{Id} \text {. } \\
& { }^{235} \mathrm{See} \text { generally I.R.S. Notice } 2016-77,2016-2 \text { C.B. } 914 \text {. } \\
& { }^{236} \mathrm{Id} \text {. The IRS noted that "[p]lacing LIHTC projects in qualified census tracts risks exacerbating } \\
& { }^{237} \mathrm{Id} \text {. } \\
& { }^{238} \text { The IRS is currently working on defining "concerted community revitalization plan." Id. It is }
\end{aligned}
$$
concentrations of poverty." Id. important to note the answer to this question is the threshold between revitalization and gentrification.

239 See Steven Cummings, Note, Twiqbal, Inc.: Finding Disparate-Impact Claims Cognizable Under the Fair Housing Act and Raising Serious Concerns in the Process, 80 ALB. L. REV. 381, 384 (2016).

Pitt Tax Review | ISSN 1932-1821 (print) 1932-1996 (online) DOI 10.5195/taxreview.2019.101 | http://taxreview.law.pitt.edu 
Communities, the Court recognized disparate impact under FHA for claims relating to the LIHTC. ${ }^{240}$ On the other hand, the Court also severely increased the difficulty in succeeding in disparate impact claims. ${ }^{241}$

In 2008, ICP, a Texas-based nonprofit that helps low-income families obtain affordable housing, sued the Texas Department of Housing and Community Affairs (Department), the housing authority responsible for distributing tax credits. ${ }^{242}$ ICP alleged that LIHTC was being administered in Texas in a manner that violates its duty to affirmatively further fair housing. ${ }^{243}$ The LIHTC projects were being approved in areas that maintained segregation. ${ }^{244}$ "As of $2013,97 \%$ of non-elderly LIHTC units . . . were located in census tracts with more than $50 \%$ minority residents." ${ }^{245}$ The plaintiffs relied on a HUD report, which states that from 1995 to 2006, 44\% of the seven county metropolitan areas with LIHTC units were in tracts with a $50 \%$ minority population. ${ }^{246}$

After $I C P$, a plaintiff making a disparate impact claim must demonstrate a causal connection between the defendant's policy and the alleged disparity, or the plaintiff must "produce statistical evidence demonstrating a causal connection" between the defendant's policy and the discriminatory effect, in order to establish a prima facie case. ${ }^{247}$ The Court, however, limited potential liability by providing private developers and HAs protection in the form of a business justification. ${ }^{248}$ The Court specified that market factors that contribute to a community's quality of life are substantial, legitimate, and (2015).

${ }^{240}$ Tex. Dep’t of Hous. \& Cmty. Affairs v. Inclusive Cmtys. Project, Inc., 135 S. Ct. 2507, 2514

${ }^{241} I d$. at 2523.

${ }^{242}$ Id. at 2508 .

${ }^{243} I d$. at 2514.

${ }^{244} I d$.

${ }^{245}$ Complaint at 17, Inclusive Cmtys. Project, Inc v. U.S. Dep't of Treasury, No. 3:14-cv-03013-D (N.D. Tex. 2014).

${ }^{246}$ Id. at 14.

${ }^{247}$ Inclusive Cmtys. Project, Inc., 135 S. Ct. at 2508.

${ }^{248}$ Id. at 2518.

Pitt Tax Review | ISSN 1932-1821 (print) 1932-1996 (online) DOI 10.5195/taxreview.2019.101 | http://taxreview.law.pitt.edu 


\section{6 |Pittsburgh Tax Review | Vol. 162019}

nondiscriminatory interests. ${ }^{249}$ The Court found that "[i]t would [otherwise] be paradoxical to construe the FHA to impose onerous costs on actors who encourage revitalizing dilapidated housing in our Nation's cities merely because some other priority might seem preferable." 250 Private developers must be given latitude to consider these market factors. ${ }^{251}$ "Zoning officials, moreover, must often make decisions based on a mix of factors, both objective (such as cost and traffic patterns) and, at least to some extent, subjective (such as preserving historic architecture). ${ }^{, 252}$ Justice Kennedy even acknowledged the heightened standard, stating that "[i]t may ... be difficult to establish causation because of the multiple factors that go into investment decisions."253

These factors would make pleading disparate impact claims difficult because the defendant can either use the factors as an affirmative defense or as an attack on the plaintiff's prima facie case. ${ }^{254}$ HUD issued a regulation interpreting the FHA to encompass a burden-shifting framework for adjudicating disparate impact claims. ${ }^{255}$ A plaintiff must first establish some prima facie showing of disparate impact. ${ }^{256}$ The plaintiff "has the burden of proving that a challenged practice caused or predictably will cause a discriminatory effect." 257 If the plaintiff cannot demonstrate the causation requirement, then there is no liability. ${ }^{258}$ If the plaintiff succeeds in presenting a prima facie case, the burden then shifts to the defendant to "prov[e] that the challenged practice is necessary to achieve one or more substantial,

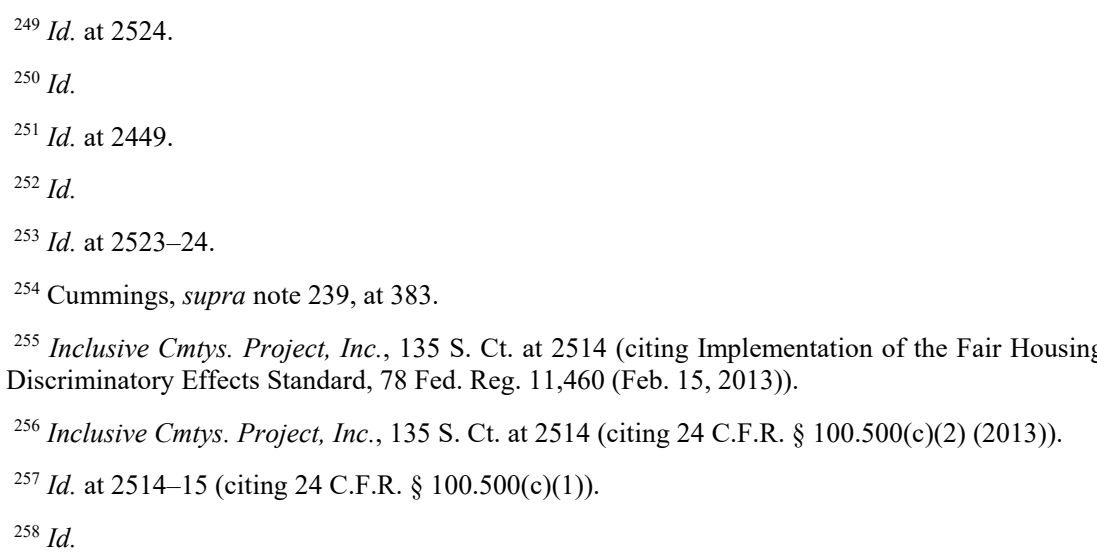

Pitt Tax Review | ISSN 1932-1821 (print) 1932-1996 (online) DOI 10.5195/taxreview.2019.101 | http://taxreview.law.pitt.edu 
legitimate, nondiscriminatory interests." 259 At this stage, the housing authority and the private developer can use the market factors to attack the plaintiff's prima facie case. ${ }^{260}$ This framework makes identifying instances of unfair housing difficult because it will be difficult for a claimant to survive the pleading stage. ${ }^{261}$

\section{Gautreaux in Light of ICP}

In Gautreaux, the Supreme Court assessed two types of public housing remedies: public housing and Section 8 low-income housing. ${ }^{262}$ The Court did not mandate either option and deferred to the lower court to decide which option would work best for remedying past discrimination engaged in by state housing agencies. ${ }^{263}$ The Court presented Section 8 as an option primarily because federal policy was steering away from a robust role in public housing. ${ }^{264}$

The problem with public housing was that local suburban communities refused to have a large public housing project in their backyard. ${ }^{265}$ Granted, the Court could have simply ordered HUD and CHA to build the housing projects in the selected suburban neighborhoods, but such an order would not receive public favor and would have been contrary to the goal of FHA. ${ }^{266}$ The purpose of FHA is to undo the history of overt racial housing discrimination, which left black communities destitute. ${ }^{267}$ If the Court had forced the

${ }^{265}$ Andrew Wilford, California NIMBYs Kill Effort to Make Housing Affordable, AM. SPECTATOR (Jan. 15, 2019, 5:45 AM), https://spectator.org/california-nimbys-kill-effort-to-make-housing-

${ }^{266} I d$. (discussing how neighborhoods argue against the building of affordable housing in their neighborhood). Section 3601 of FHA states "[i]t is the policy of the United States to provide, within constitutional limitations, for fair housing throughout the United States."

${ }^{267}$ Orfield, supra note 151 , at 1763-64.
} affordable/.

Pitt Tax Review | ISSN 1932-1821 (print) 1932-1996 (online) DOI 10.5195/taxreview.2019.101 | http://taxreview.law.pitt.edu 
placement of public housing buildings in suburban communities, the lowincome tenants may not have blended well with the community because the suburban community may not have wanted them there to begin with. ${ }^{268}$ The other option would have been placing blacks in suburban neighborhoods in moderate numbers. ${ }^{269}$ Using the private market to sprinkle blacks into different surrounding neighborhoods is easier than erecting a high-rise public housing building in a white upper- or middle-class neighborhood.

The federal government, then, increased its reliance on the private market by creating LIHTC. ${ }^{270}$ LIHTC is distinct from the Section 8 housing voucher program in two ways: LIHTC is primarily used by major corporations, while housing vouchers are feasible for both large corporations and smaller and individual landlords. ${ }^{271}$ LIHTC also generally requires new construction or some sort of renovation, while voucher programs can be used on newly constructed buildings and existing housing units. ${ }^{272}$

When ICP made its way to the Supreme Court, the Court appeared to be more hesitant to apply the same disparate impact standard to the private entities and state housing agencies administering these private programs. ${ }^{273}$

\footnotetext{
${ }^{268}$ It is known as mixed-income housing. See generally Erin M. Graves, The Structuring of Urban Life in a Mixed-Income Housing "Community," 9 CITY \& COMMUNITY 109 (2010). The idea is that placing someone with a lower socioeconomic status with higher socioeconomic status persons would enable that lower socioeconomic status person to rise up to middle-class status. Id. This is done by expanding the networks of the lower-income people, which will open them to new opportunities. Id. Scholars are split on the benefits of mixed-income housing. Compare Robert C. Ellickson, The False Promise of the Mixed-Income Housing Project, 57 UCLA L. REV. 983, 1019-20 (2010), with Matthew Shiers Sternman, Note, Integrating the Suburbs: Harnessing the Benefits of Mixed-Income Housing in Westchester County and Other Low-Poverty Areas, 44 Colum. J.L. \& Soc. ProbS. 1, 2-3 (2010). If it is clear that the community does not want that part of the community in their neighborhood, they will likely be distant from the new lower-income residents, which would not achieve the goal of neighborhood integration. Melkorka Licea, 'Poor Door' Tenants of Luxury Tower Reveal the Financial Apartheid Within, N.Y. POST (Jan. 17, 2016, 1:48 PM), https://nypost.com/2016/01/17/poor-door-tenants-revealluxury-towers-financial-apartheid/.

${ }^{269}$ See Gautreaux, 425 U.S. at 301-02.

${ }^{270}$ I.R.C. $\S 42(\mathrm{~g})(1)(\mathrm{A})$.

${ }^{271}$ Corianne Payton Scally et AL., Urban InSt., The Low-InCOME Housing TAX CRedit: HOw IT WORKS AND WHO IT SERVES 13 (2018), https://www.urban.org/sites/default/files/publication/ 98758/lithc_how_it_works_and_who_it_serves_final_2.pdf.

${ }^{272} \mathrm{Id}$. at 8 .

${ }^{273}$ Tex. Dep’t of Hous. \& Cmty. Affairs v. Inclusive Cmtys. Project, Inc., 135 S. Ct. 2507, 2523 (2015).
}

Pitt Tax Review | ISSN 1932-1821 (print) 1932-1996 (online)

DOI 10.5195/taxreview.2019.101 | http://taxreview.law.pitt.edu 
In both Texas and Chicago, the statistics demonstrate that affordable housing was located in a manner that was discriminatory. ${ }^{274}$ In Chicago, with public housing, the Supreme Court did not dispute the validity of a remedy needed to fix the discrimination, after such proof was proffered. ${ }^{275}$ In Texas, with LIHTC, the Supreme Court did the opposite. ${ }^{276}$ The Court found legitimate business decisions to be valid reasons for surviving the pleading stages of disparate impact claims. ${ }^{277}$

The Court reasoned that it wanted to protect private investors "against abusive disparate impact claims." 278 The Court stated that, "if the specter of disparate impact litigation causes private developers to no longer construct or renovate housing units for low income individuals, then FHA would have undermined its own purpose as well as the free market system." 279 In other words, Justice Kennedy seemed concerned about potential disparate impact litigation and how it would dissuade private investors from creating lowincome housing. ${ }^{280}$ Justice Kennedy laid out the framework for the justifications that a private investor or government agency that is administering credits might use to further protect private industry when undertaking to construct low-income housing:

\footnotetext{
${ }^{274}$ Id. at 2514; Gautreaux, 425 U.S. at 287-88.

${ }^{275}$ Gautreaux, 425 U.S. at $287-88$.

${ }^{276}$ Inclusive Cmtys. Project, Inc., 135 S. Ct. at 2524-25.

${ }^{277} I d$.

${ }^{278} I d$. at 2524 .

${ }^{279} I d$. at 2523. The Court shares an example:
}

A plaintiff challenging the decision of a private developer to construct a new building in one location rather than another will not easily be able to show this is a policy causing a disparate impact because such a one-time decision may not be a policy at all. It may also be difficult to establish causation because of multiple factors that go into investment decisions about where to construct or renovate housing units.

$I d$. Here, the Court is not holding private entities to the same standard that a government agency would be held to. See id. The private agency is allowed to use business reasons for not complying with FHA purposes. See id. The Court is also looking at LIHTC on a one-to-one basis as opposed to looking at it holistically. See id.

${ }^{280}$ Id. at 2523.

Pitt Tax Review | ISSN 1932-1821 (print) 1932-1996 (online) DOI 10.5195/taxreview.2019.101 | http://taxreview.law.pitt.edu 


\title{
$280 \mid$ Pittsburgh Tax Review | Vol. 162019
}

\begin{abstract}
Entrepreneurs must be given latitude to consider market factors. Zoning officials, moreover, must often make decisions based on a mix of factors, both objective (such as traffic patterns) and, at least to some extent, subjective (such as preserving historic architecture). These factors contribute to a community's quality of life and are legitimate concerns for housing authorities. ${ }^{281}$
\end{abstract}

The disregard of business justifications would threaten America's laissezfaire economic system by jeopardizing private choice in deciding where to build and how to invest money. ${ }^{282}$ Protecting the private market is a valid point. However, protecting the private market appears to outweigh providing fair housing, ${ }^{283}$ thus, we should consider swinging the pendulum back to the government to address public housing needs without furthering discrimination.

\section{PROPOSAL}

In order to reduce or eliminate discrimination in the provision of affordable housing, the pendulum should be swung back towards government control. State HAs should use tax credits to build and manage housing. Nothing in $\S 42$ appears to prohibit states from applying for LIHTC tax credits. ${ }^{284}$ Although, some states may need to expand their HAs' power to allow them to build new affordable housing, which would then permit them to apply for credits. Nonetheless, state HAs should, at the least, compete for the credits against for-profit private developers and not-for-profit developers. As any private developer can, state HAs should be permitted to send applications to their respective state, which fleshes out how their proposal is most beneficial to achieve affordable housing. Then, similar to how private developers utilize the credits, the housing authority should be allowed to sell those credits to bankers and investors to raise funds to create affordable housing.

\footnotetext{
${ }^{281} I d$.

${ }^{282}$ See generally David N. Mayer, The Myth of "Laissez-Faire Constitutionalism": Liberty of Contract During the Lochner Era, 36 HASTINGS CONST. L.Q. 217 (2009).

${ }^{283}$ See Inclusive Cmtys. Project, Inc., 135 S. Ct. at 2523.

${ }^{284}$ See I.R.C. $\S 42$. Section 42 focuses primarily on the eligibility of the proposed project and defers to the state to determine how and which projects should be chosen.
}

Pitt Tax Review | ISSN 1932-1821 (print) 1932-1996 (online) DOI 10.5195/taxreview.2019.101 | http://taxreview.law.pitt.edu 
By reigniting state control over affordable housing, the state would have direct control over the location of affordable housing, and unlike private developers, states must locate housing in a way that affirmatively furthers fair housing. ${ }^{285}$ As established in $I C P$, it is very difficult to hold private developers to fair housing standards. ${ }^{286}$ After $I C P$, it will be difficult for a litigant to survive the pleading stages because private businesses are allowed to use business rationales as a justification for locating affordable housing in a discriminatory manner. ${ }^{287}$ Conversely, as demonstrated by Gautreaux, the government is legally required to comply with fair housing law and generally cannot assert a business rationale as justification for locating housing in a discriminatory manner. ${ }^{288}$ Moreover, because HAs may sell the credits to private investors, LIHTC will still achieve its goal of generating funding from the private sector. Most beneficial, states have the potential to maximize such funding as opposed to a private organization primarily concerned with generating profits. ${ }^{289}$

In planning and developing LIHTC projects, HAs should build rental units and strategically rent them out in a way that covers expenses, generates some profits, and offers a larger percentage of affordable housing units. Instead of providing housing to only those families that are truly in need, HAs should open the doors to higher earners. ${ }^{290}$ This type of mixed housing

\footnotetext{
${ }^{285} 42$ U.S.C. $\S 3608$ (d) (2012). This puts housing back into the democratic process.
}

${ }^{286}$ Inclusive Cmtys. Project, Inc., 135 S. Ct. at 2523.

${ }^{287}$ State governments can utilize their eminent domain powers, reserved by the Tenth Amendment, to select where to build affordable housing projects. Gerald S. Dickinson, Inclusionary Eminent Domain, 45 LOY. U. CHI. L.J. 845, 888-913 (2014) (discussing the ways in which eminent domain can be used to address affordable housing).

${ }^{288}$ See supra Part III.A. On remand, the court dismissed the case because ICP was unable to point to a policy causing the racial disparity. Inclusive Cmtys. Project, Inc. v. Tex. Dep't of Hous. \& Cmty. Affairs, No. 3:08-CV-0546-D, 2016 U.S. Dist. LEXIS 114562, at *25 (N.D. Tex. Aug. 26, 2016). ICP was unable to establish that the "statistical disparity is caused by the defendant's policy or policies, rather than by other factors." Id. The court notes how many factors are taken into consideration based on the structure of LIHTC and how LIHTC is administered at the state level. Id. 25-31. Under state control, HAs would be selecting where to place LIHTC units. In the event of a HA illegally placing housing units, a litigant can easily point to the policy causing a desperate impact.

${ }^{289}$ BERG, supra note 88, at 74-75 (discussing Port Authority as an example of successful government work).

${ }^{290}$ William Julius argues that higher-income families being mixed with lower-income families provides a social buffer that opens lower-income families to more opportunities. WILSON, supra note 23,

Pitt Tax Review | ISSN 1932-1821 (print) 1932-1996 (online)

DOI 10.5195/taxreview.2019.101 | http://taxreview.law.pitt.edu 


\section{2 |Pittsburgh Tax Review | Vol. 162019}

would allow the housing authority to generate revenue, which can in turn be used to expand affordable housing to those who are in need and help middleclass families find fair and affordable housing. Ultimately, the long-term goal would be to create a self-sustaining housing authority that has its own ability to expand.

Many states call this type of free-market government entity a public authority. ${ }^{291}$ For instance, New York City had the Empire State Development Corporation (ESDC). ${ }^{292}$ ESDC was created by the state to stimulate New York's economy by financing and building projects. ${ }^{293}$ ESDC was allowed to do so by selling up to $\$ 2$ billion in bonds. ${ }^{294}$ ESDC also had the ability "to override local zoning and building ordinances as well as issue building permits. ${ }^{295}$ ESDC was responsible for the Javits Convention Center, the Marriott Marquis Hotel in Times Square, and Donald Trump's development of the Grand Hyatt Hotel. ${ }^{296}$ HAs would have low risk with the tax credits because they would not incur interest and repayment obligations associated with debt financing. ${ }^{297}$

One might argue that because we have a history of bad public housing, if we allow the same authorities to use tax credits, that bad housing history may continue. ${ }^{298}$ Government autonomy over public housing has failed in the past not because public housing cannot work, but due to improper management, cheap spending, and explicit racial discrimination. ${ }^{299}$ In its

\footnotetext{
at 56 ("[T]he exodus of middle- and working class families from ghetto neighborhoods removes an important 'social buffer' that could deflect the full impact of the kind of prolonged and increasing joblessness that plagued inner-city neighborhoods ....").

${ }^{291}$ BERG, supra note 88, at 74-75 (discussing other special purpose authorities such as MTA and Port Authority)

${ }^{292} I$ d.

${ }^{293} \mathrm{Id}$.

${ }^{294} I d$.

${ }^{295} I d$.

${ }^{296} I d$.

${ }^{297} I d$.

${ }^{298}$ Insanity is doing the same thing over and over again expecting a different result. This Note proposes that HAs need to adjust how they function.

${ }^{299}$ See supra Parts I.B-D.
}

Pitt Tax Review | ISSN 1932-1821 (print) 1932-1996 (online) DOI 10.5195/taxreview.2019.101 | http://taxreview.law.pitt.edu 
earliest iterations, public housing was founded on the idea of providing transient housing for the poor. ${ }^{300}$ The Chicago example is a prime example of mismanagement. ${ }^{301}$ The Chicago Housing Authority operated under circumstances that curtailed its public housing endeavors. ${ }^{302}$ The HAs did not carefully select tenants: "[s]ite selection was confined to black-occupied areas per the wishes of a racist city council, and high-rise projects were built with an overwhelming number of large apartments." 303 Moreover, the apartments were "tenanted strictly on the basis of eligibility and date of application with no concern about family stability or fitness to live in the community." 304 Consequently, Chicago's public housing became housing of "last resort." 305

Opponents may also argue that state HAs are plainly not in the best position to build and manage housing. ${ }^{306}$ This Note argues to the contrary; it is possible for a state to operate public housing successfully if it addresses the persistent flaws in the way public housing is operated. Currently, many of the HAs that offer public housing either are encumbered by significant debt or demolished their public housing stock because of unmanageable debt obligations. ${ }^{307}$ State HAs have difficulties with their financing because of their long history of mismanagement and cheap infrastructure. ${ }^{308}$ For instance, in New York City's public housing, the state estimates that it will cost about $\$ 31.8$ billion to fix the infrastructure, which was attributed to

\footnotetext{
${ }^{300}$ See supra Part I.

${ }^{301}$ Jim Fuerst \& Jane Sims, The Misguided Efforts to "Reform" Public Housing in America, $14 \mathrm{~J}$. AFFORDABLE HOUSING \& COMMUNITY DEV. 285, 285 (2005).

${ }^{302} I d$.

${ }^{303} \mathrm{Id}$.

${ }^{304} I d$.

${ }^{305} I d$.

306 Howard Husock, How Public Housing Harms Cities, CiTY J., https://www.cityjournal.org/html/how-public-housing-harms-cities-12410.html (last visited Apr. 15, 2019).

${ }^{307}$ See Will Bredderman, City on the Edge: The Problems, Policies, Politics and People of NYCHA, THE OBSERVER (Apr. 28, 2015, 10:30 PM), http://observer.com/2015/04/city-on-the-edge-the-problemspolicies-politics-and-people-of-nycha/. For instance, New York City Housing Authority is estimated to have a debt of $\$ 762$ million. Id. There is an extensive waiting list for Section 8 housing vouchers. Id.

${ }^{308}$ See supra Parts I.B-D.
}

Pitt Tax Review | ISSN 1932-1821 (print) 1932-1996 (online) DOI 10.5195/taxreview.2019.101 | http://taxreview.law.pitt.edu 


\section{4 |Pittsburgh Tax Review | Vol. 162019}

deteriorating and aging buildings. ${ }^{309}$ HAs can avoid such problems in the future if a well thought-out plan is used.

\section{CONCLUSION}

The government has transitioned to relying on the private market to supply affordable housing and low-income residents are getting the short end of the stick. ${ }^{310}$ Private developers prosper by getting credits, which decrease their building costs and give investors means of lowering their own tax bills. ${ }^{311}$ Meanwhile, these housing units are not located in areas that would allow tenants to end generations of poverty, even though low-income tenants receive units at an affordable rate. ${ }^{312}$ The placement of housing units in highpoverty census tracts generally leads to placing black tenants in neighborhoods that are primarily of the same race. ${ }^{313}$ This Note's proposal of allowing HAs to utilize these credits will enable states to direct the placement of affordable housing in ways that would achieve the best results for lowincome tenants. This solution would be a step towards the elimination of racial discrimination in public housing by ensuring that programs designed to subsidize low-income housing with taxpayer dollars are required to comply with the antidiscrimination standards of the FHA.

${ }^{309}$ Luis Ferre-Sadurni, What Will It Cost to Fix New York's Public Housing?, N.Y. TIMES (July 2, 2018), https://www.nytimes.com/2018/07/02/nyregion/nycha-public-housing-fix.html.

${ }^{310}$ See supra Part II.

${ }^{311}$ See supra Part II.B.

${ }^{312}$ Even when cities have promoted mixed-income housing, private developers have constructed units to keep low-income tenants separate from higher-income tenants by providing separate entrances. Licea, supra note 268 . This issue is known as the poor door. Id. Low-income tenants are completely separated from higher-income tenants. Id. Some buildings go so far as to create separate doors that do not provide low-income tenants with access to high-income tenant areas. Id.

${ }^{313}$ See supra Part IV.A.

Pitt Tax Review | ISSN 1932-1821 (print) 1932-1996 (online)

DOI 10.5195/taxreview.2019.101 | http://taxreview.law.pitt.edu 